\title{
Kentsel dönüşüm sürecine yönelik anahtar bir çerçeve ve Konya deneyimi ${ }^{\dagger}$
}

\author{
Nurullah OSMANLI' ${ }^{1}$ Kübra KOÇER ${ }^{2}$, Neslihan SERDAROĞLU SAĞ ${ }^{2, *}$ \\ ${ }^{1}$ Konya Büyükşehir Belediyesi, Imar ve Şehircilik Dairesi Bşk., Konya \\ ${ }^{2}$ Konya Teknik Üniversitesi, Mim. ve Tasarım Fak., Şehir ve Bölge Planlama Böl., Gelişim Yerleşkesi, \\ Konya
}

Geliş Tarihi (Received Date): 09.04.2019

Kabul Tarihi (Accepted Date): 30.01.2020

\section{$\ddot{\mathbf{O} z}$}

Günümüze kadar kentsel bozulma sorunlarını çözmek için kentlere özgü birbirinden farklı kentsel dönüşüm süreçleri yaşanmıştır. Kamu sektörü tarafindan uygulanan kentsel dönüşüm projeleri çoğunluğu oluştursa da kentsel dönüşüm çabalarının sürdürülebilirliğini sağlamak için toplum ve özel sektörün sürece dâhil edildiği ortaklık modelleri ile daha başarılı bir süreç yaşanabileceği kabul edilmektedir. Dünya örnekleri kentsel dönüşüm için kullanılan politika, düzenleyici araçlar, halk katılımı ve yönetim yapısı bakımından farklılı gösterse de ortak nokta olarak kentsel alanların yenilenmesi, yeniden canlandırılması, kültürel bağlamlarını devam ettiren kimlikli ve yaşanabilir mekânlar haline getirilmesi çabaları olarak ortaya çıkmaktadır. Bu çalışma, kentsel dönüşüm projelerinin tasarlanması ve uygulanmasina yönelik farklı örnekleri değerlendirerek, kent yöneticileri ve plancılart için kentsel dönüşüm sürecinin kavranmasına yönelik pratik bir araç oluşturmak üzerine kurgulanmıştır. Makale iki bölümden oluşmaktadır. İlk bölüm kentsel dönüşüm sürecini kapsam belirleme, planlama, finansman ve uygulama olmak üzere 4 aşama ile dünya örnekleri üzerinden tariflemektedir. Bu araştırmalar sonucunda kentsel dönüşüm sürecinde nasıl bir yol izlenebildiğine yönelik çıkarımlar oluşturulmuştur. İkinci bölümde ise ilk bölümde aktarlan aşamalar, Konya Kenti tarihi kent merkezi kentsel dönüşüm sürecinde ele alınarak deneyimler tartışılmıştır. Sonuç olarak, Konya kentsel dönüşüm deneyiminde kendine ait bir süreç oluşturduğu ve uygulama ve finansman aşamalarında eksikliklerin olduğu tespit edilmiş ve buna yönelik öneriler aktarllmıştır.

Anahtar kelimeler: Kentsel dönüşüm süreci, planlama, finansman, uygulama, Konya.

\footnotetext{
Nurullah OSMANLI, osmanlinurullah@gmail.com, http://orcid.org/0000-0002-9077-061X Kübra KOÇER, kubrakarkin@gmail.com, http://orcid.org/0000-0001-9610-3052

*Neslihan SERDAROĞLU SAĞ, nssag@ktun.edu.tr, http://orcid.org/0000-0001-8002-4499

† Bu makale, Konya Teknik Üniversitesi Lisansüstü Eğitim Enstitüsü, Şehir ve Bölge Planlama Anabilim Dalı doktora programında 2018-2019 Öğretim yılı güz döneminde Dr. Öğr. Üyesi Neslihan Serdaroğlu Sağ tarafından yürütülen Kentsel Dönüşüm Modelleri ve Uygulamaları dersi kapsamında hazırlanmıştır.
} 


\title{
A key framework for urban regeneration process and Konya experience
}

\begin{abstract}
Different urban regeneration processes have been designed to solve urban deterioration problems. Although the urban regeneration projects implemented by public sector in general constitute a majority, it is accepted that a more successful process can be experienced with the association of public and private sector in order to ensure the sustainability of urban regeneration efforts. The common of world examples are the efforts to make the urban areas renew, revitalize and become habitable areas that continue their cultural contexts. This paper was designed to provide a practical tool for urban managers and planners by evaluating different examples of urban regeneration projects' design and implementation. The article consists of two parts. The first section describes the process of urban regeneration through four stages, including scope, planning, financing and implementation. In second part, the urban regeneration process of the historical city center of Konya was discussed by four stages. It has been determined that Konya constitutes its own process in urban transformation experience and there are deficiencies in implementation and financing stages and suggestions are provided for this.
\end{abstract}

Keywords: Urban regeneration process, planning, financing, implementation, Konya.

\section{Giriş}

Sanayi Devrimi ve II. Dünya Savaşı sonucunda kentler, ekonomik aktivite ve nüfusta yaşanan değişimlere yönelik olarak mekânsal ve sektörel yapılarında düzenlemeler yapmak zorunda kalmıştır [1]. Küresel düzeyde rekabet eden kentler, altyapı geliştirme ve kent hizmetleri arasında denge oluşturma zorunluluğunda kalarak, ekonomik ve sosyal değişimler/baskılar sonucunda yayılmış ve yeniden yapılanma süreçleri yaşamaya başlamıştır. Hızlı kentleşme süreci ile kentlerin aşırı yayılması ve büyümesine bağlı olarak, kent merkezlerinde gecekondu alanları gibi yasadışı yerleşmeler ve/veya zaman içerisinde eski canlılığını yitirmiş, atıl kalmış, altyapı ve donatı alanlarından yoksun, yıpranmış ve güvenlik problemlerinin de yaşandığı çöküntü alanları ortaya çıkmıştır. Bu problemlerin çözümünde araç olarak ortaya çıkan kentsel dönüşüm projeleri son dönemde oldukça önemli bir tartışma alanı olarak karşımıza çıkmaktadır.

Kentsel dönüşümün temel amacı bozulan/köhneleşen kent mekânını yaşanabilir hale getirmektir. Dönüşüm kavramı gelişmişlik düzeyinin etkisiyle her ülke tarafından farklı şekillerde yorumlanmaktadır. Gelişmiş ülkelerde genel hatlarıyla dönüşümde amaç, akıllı büyüme yoluyla çevrenin kalitesini artırmak ve kent merkezini yeniden canlandırmaktır [2]. Bu amacın tersine, kentsel dönüşümün rant olarak algılandığı ve kentliler için olumsuz sonuçlar oluşturduğu birçok ülkede birçok örnek bulunmaktadır. Dönüşüm yıkıp yeniden yapmak olarak algılanmakta ve dönüşüme ihtiyaç duyan alanlardan ziyade rantı yüksek alanlarda dönüşüm projeleri uygulanmaktadır. Türkiye'de de bu algının örneklerini görmek mümkündür [3]. 
Kentsel dönüşüm kavramı, yaklaşımına ve yorumlanmasına bağlı olarak, çok geniş bir tanımlama içermektedir [4-7]. Roberts, kentsel dönüşüm kavramını "kentsel sorunların çözümüne yol açan ve değişime uğramış bir alanın ekonomik, fiziksel, sosyal ve çevresel koşullarında kalıcı bir iyileşme sağlamayı amaçlayan kapsamlı ve bütünleşik vizyon ve eylem" olarak tanımlamaktadır. Kentsel dönüşümde, alanın koşullarının detaylı şekilde ortaya konulması, fiziksel, ekonomik ve sosyal yapıya ilişkin durumlara adapte olabilecek şekilde hedef geliştirilmesi, sürdürülebilir gelişmeyi amaçlaması, düzenleme araçlarının net şekilde ortaya konulması, tüm kaynakların en uygun şekilde kullanılması ve tüm paydaşların işbirliği ve katılımının sağlanması gerekmektedir [4, 8, 9]. Dönüşüm süreçlerinin farklılıklarının incelenmesi benzer örneklerden çıkarımlar oluşturmaya yardımcı olacaktır $[4,9,10]$.

Bu makale, kentlerde ortaya çıkan köhnemenin giderilmesine yönelik gerçekleştirilen örnek kentsel dönüşüm süreçlerinin ve deneyimlerinin aktarılmasına odaklanmaktadır. Makale literatür araştırması ve alan çalışması olmak üzere iki bölümden oluşmaktadır. İnternet ve kütüphane taramalarından elde edilen makale, tez, kitap vb. yerli ve yabanc1 kaynaklar ile Konya Büyükşehir Belediyesi ve Meram Belediyesi'nden elde edilen haritalar, planlar, raporlar, yazılı ve görsel kaynaklar çalışmanın materyallerini oluşturmaktadır. İlk bölüm, kentsel dönüşüm sürecini kapsam belirleme, planlama, finansman ve uygulama olmak üzere 4 aşama ile dünya örnekleri üzerinden tanımlamaya yönelik literatür çalışmasıdır. İkinci bölüm ise literatür araştırmasında sentezlenerek aktarılan aşamalar halinde, Konya Kenti tarihi kent merkezi dönüşüm süreci ele alınarak deneyimlerin tartışıldığı alan çalışmasıdır. Bu makalede yabancı ülke örneklerindeki kentsel dönüşüm süreçleri ile Konya tarihi kent merkezi örneğinde izlenilen süreçteki farklılık ve benzerlikler ortaya konulmuş ve problem yaşanan noktalara ilişkin tespitlerde bulunulmuştur. Kentsel dönüşüm proje süreçlerinin irdelenmesi ile çıkarılan dersler, yeni üretilecek projelerde daha sağlıklı adımlar atılmasına katkı sağlanması yönünden önem taşımaktadır.

\section{Kentsel dönüşüm sürecine yönelik genel çerçeve}

Her kent mekânı birbirinden farklı problem ve dinamikleri içermektedir. Bu bağlamda kentsel dönüşüm geniş ve kapsamlı bir sürece ihtiyaç duymaktadır. Literatürde, kentsel dönüşümün kapsam belirleme, planlama, finansman ve uygulama aşamalarına odaklanan farklı nitelikte kaynaklar bulunmaktadır [7-9]. Makale bu anlamda örnek çalışmaları bir arada değerlendirmeye imkân sunmaktadır. Kentsel dönüşüm sürecine ilişkin genel bir çerçeve oluşturulabilmesi adına dört aşama (kapsam belirleme, planlama, finansman ve uygulama) benimsenerek irdelemeler gerçekleştirilmiş̧tir.

Kentsel dönüşüm projelerinin kapsamının belirlenmesi ve etkilerinin ortaya konması ilk adımdır ve proje için analitik bir temel oluşturmakta ve amaçlar belirlenmektedir. Planlama aşaması, kentsel dönüşümle ilgili olarak uzun dönemde izlenecek yol ve yöntemler ile tasarım sürecinin gerçekleştirildiği çalışmaları içermektedir. Kentsel dönüşümde oldukça önemli olan bir diğer temel adım ise finansmanın belirlenmesidir. Projelerin uygulanabilirliğinde en temel ön şart olarak tanımlanan bu aşama, fayda maliyet analizleri ile proje sonrası oluşan değerin dağıtımı ve projenin maliyetini karşılamaya dönük kullanılan finansal kaynakların belirlenmesini içermektedir. Dördüncü aşama ise uygulamadır. Bu son aşama, hukuki sınırlamalar, haklar, etaplamalar vb. uygulama araçları ve projenin tamamlanmasına yönelik eylemleri içermektedir $[8,9]$. 
Burada belirtilen süreç bağlamında, dünyanın farklı kentlerinden kentsel dönüşüm örnekleri incelenmiştir. Alan özellikleri ve sorunların ölçeğine göre farklılıklar barından örnekler üzerinden tartışma gerçekleştirilmiştir. Gecekondu alanlarının dönüşümünü içeren Angola-Luanda metropoliten alan çalışması, ortaklık modeli sunan bütünleşik bir yaklaşıma dayanmaktadır. Çin'in önemli merkezlerinden Şangay tarihi kent merkezinin dönüşüm projesi, metropol bütününde yürütülen rekabet stratejisi doğrultusunda gerçekleştirilmiştir. İtalya Umbria Bölgesi tarihi kent merkezinin dönüşümünü, mülkiyet hakkı transferi aracıyla gerçekleştiren koruma odaklı bir örnektir. Güney Afrika Cumhuriyeti'nde Cape Town ve Johannesburg deneyimleri incelenmiştir. Cape Town merkezi iş alanının dönüşüm projesi, ulusal strateji doğrultusunda alan odaklı yaklaşımla gerçekleştirilmiş ve ana odak yoksulluk ve az gelişmişlik olmuştur. Johannesburg kent merkezi örneği, yıllardır kentte yaşanan ayrışma ve bozulmanın çözümüne odaklanmıştır. Tüm paydaşların etkin şekilde rol almasını amaçlayan projede suçu minimize etmek üzere tasarım yapılmıştır. İngiltere Newcastle örneği, geniş bir katılım süreci gerçekleştirmeyi hedefleyen toplum odaklı bir yaklaşım geliştirmiştir.

Angola'nın başkentinin Luanda metropoliten alanı kentsel dönüşüm süreci, kapsamlı bir çerçeve çizmesi bakımından önemli bir örnektir. Tüm dünyada yaşanan hızlı kentleşme sürecinin olumsuz etkilerinin bir örneği olan Luanda'nın büyük çoğunluğu (\%80'i) yasadışı yapılaşmalardan oluşmaktadır. Göç ve kent politikalarındaki istikrarsızlığın da bir sonucu olarak ortaya çıkan süreç, karmaşık bir yapıyı çözmek için bütüncül bir yaklaşımın esas alınması gerektiğini ortaya koymuştur. Projenin kapsamı, daha önceki dönüşüm deneyimlerinden yola çıkılarak belirlenmiştir. Paydaşların koordinasyonunu sağlayan etkili bir dönüşüm modeli hedeflenmiştir. Dönüşüm modelinde sosyal, ekonomik ve çevresel tüm faktörlerin bütünleştirilmesi ve tüm nüfusun kentsel dönüşüm hareketine katılımının sağlanması amaçlanmıştır. Yapılaşmış alandan uzak bir yer seçimi yapılmıştır. Bu sayede, yıkıp yeniden yapmak yerine alanın yerel koşullarına ve pozitif özelliklere odaklanan yeni bir yöntem geliştirilmiştir. Planlama aşaması; dönüşüm sürecinde gerçekleştirilen kamu yatırımları yerel özellikleri dikkate alarak ve yasal çerçeve içerisinde kalarak, nüfusun ihtiyaçlarına cevap verecek şekilde tasarlanmıştır. Finansman olarak kamu tarafindan arazi bankası oluşturulmuş ve özel sektör için gelişmeyi destekleyen teşvik ve tazminat sistemine göre tüm paydaşlar için uygun bir yaklaşım geliştirilmiştir. Uygulama aşamasında, tüm paydaşların süreçteki net rolleri tariflenmiş ve kamunun kolaylaştırıcı; özel sektörün destekleyici olduğu bir proje hayata geçirilmiştir. Hak transferlerinde resmi ve gayri resmi kişileri esas alan ilkeler kullanılmıştır [5].

Çin'in Şangay Kenti Luwan Bölgesi Taipingqiao Mahallesi'nde bulunan Xintiandi bölgesinde gerçekleştirilen dönüşüm çalışması, gecekondu alanlarının yenilenmesini amaçlamıştır. Proje, Şangay'ın dönüşüm programının (365 programı) ilk pilot uygulaması olarak, mekânın ruhunu ve kimliğini korumayı amaçlayan tarihi kent merkezinin yeniden geliştirilmesinin başarılı bir örneği olma iddiası taşımıştır. 1990'l1 yıllarda başlayan Şangay'ın dönüşümü, 365 ha büyüklükte bir alanı kapsamaktadır. Luwan bölgesi, bu alanın 100 ha; Xintiandi ise 3 ha büyüklüğündeki kısmını içermektedir. Tarih boyunca sosyal bakımdan birçok değişime uğrayan alan, zaman içerisinde yavaş yavaş bozulmuş ve süreç sonunda ilk sahipleri alanı terk etmiştir. 1990'l1 yıllarda alandaki yapıların çoğu tahrip edilmiş ve yaşam koşulları hem güvensiz hem de sağlıksız hale gelmiştir. Şangay konut ve ticaretin geliştiği hızlı bir kentsel dönüşüm dönemine şahit olmuştur [11]. 
Planlama aşamasının ilk adımı çalışma alanını içine alan mahalle için master plan hazırlanması olmuştur. Yerli ve yabancı sermayenin projelere dâhil edildiği karma bir arazi kullanım şeması oluşturulmuştur. Taban oranları, yeşil alanlar, otopark vb. birçok yasal düzenleme geliştirilip, parametre ve özgünlükler belirlenmiştir. Planlama çalışmaları projenin geliştirici haklarını sağlayan özel bir şirket ortaklığı ile yürütülmüştür. Kamunun dönüşümdeki rolü ise, arazinin sağlanması ve etkilenen nüfusun yeniden ikamet ettirilmesi olmuştur. Bölge ve kent için önemli bir değer olan Xintiandi bloklarının tarihi dokusunun korunması ve planlama sürecinde ortaya çıkan finansal kriz, firma için risk unsurları olarak karşımıza çıkmaktadır. Hükümetin Şangay'ın önemli kentsel alanları proje alanına bağlayan metro hatları gibi taahhütleri, özel sektörün proje hakkındaki çekincelerini zayıflatmıştır. Sürecin bir aşaması olan müzakere ve alanda yaşayan nüfusla görüşmeler de kurulan şirket aracılığıyla gerçekleştirilmiştir. Bu düzenleme, yerel yönetimin ve özel geliştiricinin konut sakinleriyle doğrudan müzakere etmesini engellemiştir [11].

Gerçekleştirilen dönüşüm projesi ile alan, önemli sosyo-ekonomik, politik ve kültürel faydalar sağlamış ve kentin uluslararası düzeyde tanınırlığını artırmıştır. Projenin finansmanı, alanda yer alan blokların inşasından elde edilen kârla sağlanmak istenilmiştir. Dünya standartlarında olanaklar sağlayan proje, yerel yönetimin gelirinin artmasına neden olmuştur. Tarihsel olarak önemli fakat harabe durumda olan bir mahalleden önemli bir değer üretilmiştir. Fakat yaratılan değerler ve geliştirilen olanaklar, asıl sakinlere doğrudan fayda sağlamamıştır. Uygulama aşamasına yönelik, karar verme süreçlerine halk dâhil olmamış; yalnızca daha iyi bir yaşam talepleri modern, yeni fakat alana uzak konutlara taşınarak sağlanmıştır [11].

Dönüşüm kavramının ortaya çıktığı ilk ülke olan İngiltere'de özellikle finansman bakımından örnek teşkil edebilecek bir çalışma incelenmiştir. Kentsel dönüşümde finansman önemli bir yer tutmaktadır. Çalışmanın kapsamı; Manchester, Newcastle ve Londra' daki kentsel dönüşüm yatırımcıları ile odak grup görüşmesi gerçekleştirilmesi ve kentsel dönüşüm politikalarının sosyal yönleriyle daha çok ilgilenilmesidir. Planlama aşamasında; odak grup toplantıları, dönüşüm süreçlerinde etkili olan ve etkilenen tüm paydaşlarla gerçekleştirilmiştir. Çalışmanın çıkış noktası kentsel dönüşümün gerçekleştirileceği alanların özel sektör tarafından risk ve belirsizlik alanları olarak ele alınması olmuştur. Dönüşüm alanlarının olumsuz imajı, pazar koşullarının ağırlaşması ve arazi değerlerinin değişkenliği başlıca risk unsurları olarak tanımlanmıştır [12].

Çalışma süresince gerçekleştirilen görüşmeler sonucunda; projelerin desteklenmesi için uzun vadeli yatırım araçlarında kamu ve özel fonların toplanması, bölgesel yatırım şirketlerinin ve gayrimenkul ortaklıklarının kurulmasına yönelik finansman düzenlemeleri önerilmiştir. Bu düzenlemeler, kentsel dönüşümde kamu varlığının en etkin biçimde kullanılmasının ve özel sektörden daha fazla yatırıma erişebilmesinin ana dayanak noktası olarak tanımlanmıştır. Uygulama aşamasında; kentsel dönüşüm sürecinde özel sektörle ortaklaşa yürütülen, yerel düzeyde bütüncül ve entegre yaklaşımların benimsenmesi vurgulanmış ve süreçte yönlendirici olmuştur [12].

Güney Afrika Cumhuriyeti'nin en büyük ve önemli kentlerinden biri olan Johannesburg'da girişimci, işbirlikçi örgütlenme ve bireysel girdileri bir arada yorumlayan, 400.000 kişinin yaşadığ 1 bir alanı kapsayan kent merkezi dönüşüm süreci bir başka örnek olarak incelenmiştir. Özel sektör girişimiyle başlayan proje, sonrasında devlet desteği ile devam etmiştir. Yaşanabilir, güvenli, iyi yönetilen bir dönüşüm vizyonu 
oluşturulmuştur. Irkçı-ayrımcı ve referandumcu politikaların yıllar içindeki etkileri ve kentin mekânsal ve demografik özelliklerini değiştiren siyasi geçişin etkileri ile zamanla Johannesburg kenti çöküşe geçmiş ve 1990'l1 yıllara kadar da bu çöküş devam etmiştir. Kent merkezi çok sayıda harabe yapıya sahip olmuştur. Farklı ırkların bir arada yaşaması, kamusal mekânların azalması ile suç oranlarında artış ve yatırımlarda düşüş yaşanmıştır. Planlama aşamasında; 1994 yılında, temiz ve güvenli merkezlerin geliştirilmesi, kompakt gelişimin desteklenmesi, canlı ticari merkezlerin teşvik edilmesi ve dönüşüm ortaklıkları oluşturulması hedeflerini kapsayan plan ile kent merkezi için bir kentsel dönüşüm süreci başlatılmıştır. Sürece dâhil olan çok sayıda kurum, aktör ve sektör bulunmaktadır [13].

Projenin sermaye bütçesi yerel yönetim tarafindan sağlanmaktadır. Çok sayıda sahipsiz ve harabe konutların yer aldığı alanın dönüşümünde, yönetim tarafindan oluşturulan gelişme/ iyileştirme alanı (CID-mülk sahiplerinin ek hizmetler ve kentsel çevrenin iyileştirilmesi için ödeme yapmayı kabul ettiği, sınırları tanımlı bir coğrafi alan) kurulması büyük başarı getirmiştir. Özel finansman kullanarak kent yönetimine ve hizmetlerine katkıda bulunmuştur ve bu bölgelerde suç oranları ciddi oranda azalmıştır. Kayı1 dış1 sektörü (ticaret) yönetmek için ortak bir girişim düzenlenmiş ve kayıtlı ticarete zarar vermediği sürece kabul edilebilir bir etken olarak karş1lanmıştır. Uygulama aşamasında; daha iyi yapılar programı kurularak terkedilmiş binaların kamulaştırma ve satışı sağlanmış, rehabilite edilmiş ve yönetme kapasitesi ve sermayesi olan özel sektör kuruluşları için kolaylaştırılmıştır. Johannesburg kent merkezinin dönüşümünün en özgün özelliği aktif bir özel sektör topluluğu, göçmen işçiler, kamu hizmeti şirketleri ve ulusal ve yerel yönetimler gibi aktörlerin ve paydaşların çokluğudur. Johannesburg dönüşümü geniş bir yelpazedeki paydaşların çeşitli süreçler ve çerçeveler aracılığıyla işbirliği yapabilmelerinin ve bunların bir araya getirilmesinin mümkün olabildiğini kanıtlanmıştır [13].

Güney Afrika Cumhuriyeti'nde ulusal çapta başlatılan dönüşüm programının önemli ayaklarından olan Cape Town'un Khayelitsha merkezi iş alanının dönüşüm süreci incelenen bir diğer örnek olmuştur. Zaman içinde ırkçı hükümetin gerçekleştirdiği planın yaşanabilir bir Khayelitsha oluşturmadığ 1 ve monoton konut alanlarından ibaret bir alan ürettiği ortaya çıkmıştır. Alan temelli bir yaklaşımı esas alan projenin kapsamı, alanın niteliğini paydaşlar ve kurumlara bağlı olarak değiştirebilme imkânı sunmuştur. Daha önce planda çalışma alanı/ ticari bir fonksiyon öngörmemektedir; fakat marjinal sektörlere yönelik ticaret zamanla alanda oluşmuştur. Planlama aşaması; kentin yenilenmesinin sağlaması ve ırkçı dönemin geri kalmışlığını ortadan kaldırmak amacıyla tasarlanmış olan yaklaşım çerçevesinde, güçlü ulaşım bağlantıları ve açık alanların bütünleşmesiyle mekânsal entegrasyon sağlanmıştır. Uygulanma sürecinde; ilk aşamada perakende ticaret, altyapı, kamu ve donatı alanları gibi fonksiyonlar gerçekleştirilmiştir. İkinci aşamada ofis ve üniversite alanları, polis merkezi gibi kullanımlar tamamlanmıştır. Çalışma ile çeşitli kazanımlar elde edinilmiştir. Sürecin hızlandırılması ve özel sektör ve kamu yatırımlarının istenen düzeyde olması için daha basit-rahat bir proje yönetimi sağlanmış, büyümenin bir parçası olan gerçeklikler (örnekteki seyyar satıcılar gibi) dikkate alınmıştır. Özellikle bürokratik süreçlerin yönetimini sağlayan ve farklı roller üstlenen bir yapıya kavuşturulmuştur. Gerçekleştirilen pilot proje ile dönüşüm projelerinin uzun dönemli sürdürülebilirliği için kentte sağlam bir zemin oluşturulmuştur $[6]$.

Kentsel dönüşüm uygulamalarında sık sık yer edinen tarihi kent merkezleri ve mülkiyet hakkı transferi İtalya'nın Umbria bölgesi tarihi kent merkezi üzerinden incelenmiştir. 
Umbria bölgesi, uygulamanın İtalya'da gerçekleştiği ilk alan olma özelliğine sahiptir. Kapsam belirleme aşamasında koruma temel dayanak olmuştur. Koruma konusunda oldukça deneyimli olan İtalya'da projedeki dönüşümün amacı, kültürel ve tarihi dokunun korunmasına yönelik olarak geliştirilmiştir. Tarihi merkezin zayıf ve güçlü yönleri, stratejik eylemleri, uzun dönemli kalkınma politikaları ve alanda baskın ekonomik sektörün belirlenmesinin ardından öncelikli dönüşüm alanları belirlenmiştir. Planlama aşamasında; öncelikli olarak özel mülkiyet sahipleri tarafından bir dönüşüm eylem planı hazırlanması zorunlu kılınmıştır. İmar hakkıyla ilgili yapılar, 14 ha' dan küçük belediyeler için $500 \mathrm{~m}^{2}$ brüt alan ve diğerleri için $1000 \mathrm{~m}^{2}$ 'lik brüt alana sahip olmak zorundadır. Bir çeşit plan belgesi olan, stratejik eylemleri, uzun dönemli kalkınma politikalarını ve alanda baskın ekonomik sektörü belirleyen QVS (İyileştirme ile ilgili stratejik belge) ve öncelikli dönüşüm alanlarının belirlendiği APR (Öncelikli dönüşüm alanlarının belirlenmesi) belgelerinin hazırlanmış olması gerekmektedir. Nicel ve ekonomik koşulların yerine getirilmiş olması ile hak transferi etkin bir araç olarak kentsel dönüşümde başarılı şekilde kullanılabilmektedir. Kentsel dönüşüm planları, genel plan hüküm ve bölgelemeleri ve arazi kullanım kararları ile eşgüdümlü gerçekleştirildiği için süreç daha hızlı ve daha başarılı yürütülmüştür. Finansman modeli olarak; kamu-özel ortaklığına dayalı bir yaklaşım kullanılmıştır [14].

Uygulama aşamasında; İtalya'da düzenleme aracı kavramı ile ortaya çıkan mülkiyet hakkı transferi ile alanın korunması, tarihi ve kültürel merkezlerin koruma ve restorasyonu, arazi sahipleri arasında eşit hak dağılımı sağlanmıştır. Aynı zamanda, uygulama ile yetki yerel sektöre aktarılmıştır. Çıkarılan kanunla bölgede imar hakkının getirdiği bonus hakkın kullanılma olanağı tanınmıştır. İmar hakkı transferi maliyet avantajı sağlayan bir planlama aracı olarak kullanılmıştır. Mülk sahiplerine dönüşüm ve iyileştirme projelerinde verilen ve yalnızca tarihi kent merkezi dışarısında kullanılan bir hakkın verilmesi için belirli şartlar getirilmiştir. [14].

Kentsel dönüşüm uygulamalarında müdahalelerin nüfus üzerinde farklı yönde etkileri bulunmaktadır. Bu etkilerden biri olan soylulaştırma, İngiltere'nin Newcastle kentinde incelenmiştir. Süreç 1999 yılında başlamış ve 6600 yapıyı içine almaktadır. Kent çapında gerçekleştirilen dönüşüm programını kapsayan ve soylulaştırma kavramı çerçevesinde bir kapsam belirlenmiştir. İngiltere' deki ilk büyük ölçekli örnek olmuştur ve toplum temelli bir yaklaşım çerçevesinde öneriler getirilmiştir. Kentten sanayinin desantralizasyonu ve nüfusun azalması ile alan ciddi büyüklükte göçe sahne olmuştur. Sonucunda ise, konut ve arazi piyasasının düşüşü, suç oranları arttığı ve parçalanmış ve kutuplaşmış bir kent ortaya çıkmıştır. Sosyal kutuplaşmada büyüyen uçurum ve nüfus problemlerinin çözümü için tüm kent çapında benimsenmiş olan 'Going for Growth' programında dönüşüm, çok yönlü kalkınmanın sağlanmasını hedeflemiştir [15].

Planlama aşaması için 4 farklı bölgeleme oluşturulmuş ve her bölge kendi içerisinde halkın katılımının sağlandığı bir süreçte değerlendirilmiştir. Geniş çapta danışma süreci yürütülen programın hedef yılı 2020'dir. Finansman olarak özel geliştiriciler ile süreç ilerlemiştir [15]. 
Tablo 1. Farklı kentsel dönüşüm projelerinde süreç ve uygulamalar.

\begin{tabular}{|c|c|c|c|c|c|c|}
\hline $\begin{array}{l}\text { Uygulam } \\
\text { a Ölçeği }\end{array}$ & Ülke & $\begin{array}{l}\text { Örnek } \\
\text { Alan }\end{array}$ & Kapsam & Planlama & Finansman & Uygulama \\
\hline $\begin{array}{c}\text { Kent } \\
\text { Merkezi } \\
\text { Örnekleri }\end{array}$ & $\begin{array}{l}\text { Çin Halk } \\
\text { Cumhuriyet } \\
i\end{array}$ & $\begin{array}{l}\text { Luwan- } \\
\text { Taipingqiao } \\
\text { Mahallesi- } \\
\text { Xintiandi } \\
\text { Bölgesi } \\
\text { Tarihi Kent } \\
\text { Merkezi }\end{array}$ & $\begin{array}{l}\text { Özel bir şirket } \\
\text { ortaklığı ile } \\
\text { yürütülmüştür. } \\
\text { Şirketin rolü: } \\
\text { Yer değiştirme } \\
\text { tazminatı, } \\
\text { y1kım ve } \\
\text { yeniden } \\
\text { yerleştirmeyi } \\
\text { işletmektir. } \\
\text { Kamunun rolü: } \\
\text { Geliştirme } \\
\text { haklarını } \\
\text { sağlamaktır. }\end{array}$ & $\begin{array}{l} \\
\text {-Taipingqiao } \\
\text { Mahallesi'ni de } \\
\text { kapsayan } \\
\text { master plan } \\
\text { (1997) } \\
\text { •Şangay } \\
\text { Planlama } \\
\text { Departmanı } \\
\text { uygulamayı } \\
\text { hızlandırmak } \\
\text { için } \\
\text { basitleştirilmiş } \\
\text { onay } \\
\text { prosedürleri } \\
\text { sunmuştur. } \\
\text { •Yapplaşma } \\
\text { koşulları } \\
\text { yumuşatılmıştı } \\
\text { r. }\end{array}$ & $\begin{array}{l}\text { •Konut ve ofis } \\
\text { alanından gelen } \\
\text { yatırım getirisi, } \\
\text { Taipingqiao gölü } \\
\text { ve parkının } \\
\text { inşasını } \\
\text { desteklemiştir. } \\
\text { •Şirket, } \\
\text { Taipingqiao'nun } \\
\text { tamamını } \\
\text { yeniden } \\
\text { geliştirerek, } \\
\text { Xintiandi'nin } \\
\text { korunması } \\
\text { sağlanmıştır. } \\
\text { •Yeniden } \\
\text { yerleştirme } \\
\text { maliyetini şirket } \\
\text { ödemiştir. }\end{array}$ & $\begin{array}{l}\text { - Uygulama ve } \\
\text { proje aşaması, } \\
\text { makroekonomik } \\
\text { koşullara ve konut } \\
\text { talebine etkilerine } \\
\text { göre } \\
\text { belirlenmiştir. } \\
\text { Erken yatırım, } \\
\text { konut ve ofis alanı } \\
\text { yerine tarihi } \\
\text { alanın ve kentsel } \\
\text { kamusal alanın } \\
\text { yeniden } \\
\text { geliştirilmesine } \\
\text { odaklanmıştır. } \\
\text { • Luwan } \\
\text { Bölgesi'ndeki } \\
\text { gayrimenkul } \\
\text { geliştirme şirketi } \\
\text { ve SOL şirketi } \\
\text { ortak bir girişim } \\
\text { başlatmıştır. } \\
\end{array}$ \\
\hline & $\begin{array}{l}\text { Güney } \\
\text { Afrika } \\
\text { Cumhuriyet } \\
i\end{array}$ & $\begin{array}{l}\text { Johannesbur } \\
\text { g Kent } \\
\text { Merkezi }\end{array}$ & $\begin{array}{l}\text { Birçok vizyon } \\
\text { ve plan } \\
\text { geliştirilmiştir; } \\
\text { fakat bu } \\
\text { planların çoğu } \\
\text { uygulama } \\
\text { düzeyinde } \\
\text { ayrıntı } \\
\text { içermemektedi } \\
\text { r. }\end{array}$ & $\begin{array}{l}\text { •2004, Kent } \\
\text { Merkezi } \\
\text { Dönüşüm Planı } \\
\text { •2007, Kent } \\
\text { Zirvesi ve } \\
\text { Konut Eylem } \\
\text { Planı } \\
\text { •2013, Kent içi } \\
\text { Dönüşüm Yol } \\
\text { Haritası }\end{array}$ & $\begin{array}{l} \\
\text { •İyileştirme } \\
\text { alanları ilanı } \\
(C I D), \\
\text { •Ulusal düzeyde } \\
\text { vergi teşvikleri, } \\
\text { •Kentsel Konut } \\
\text { Vakfı } \\
\text { - Sermaye } \\
\text { bütçesi yerel } \\
\text { yönetim ve diğer } \\
\text { hükümet } \\
\text { departmanlarında } \\
\text { n karşılanan } \\
\text { kalkınma ajansı }\end{array}$ & $\begin{array}{l}\text { - Kent içi özel } \\
\text { sektör } \\
\text { yatırımlarını } \\
\text { artırmayı } \\
\text { hedefleyen } \\
\text { projeler } \\
\text { gerçekleştirilmişti } \\
\text { r. } \\
\text { - Ajansın bölgeye } \\
\text { dayalı } \\
\text { girişimlerinde } \\
\text { kaldırma oranı } \\
\text { yüksektir. } \\
\text { - Suç önleme } \\
\text { önlemleri } \\
\text { alınmıştır. } \\
\text { • Kamu sanatları } \\
\text { ve kamusal alan } \\
\text { tasarımları } \\
\text { • Daha iyi yapılar } \\
\text { programı } \\
\text { geliştirilmiştir. } \\
\end{array}$ \\
\hline & $\begin{array}{l}\text { Güney } \\
\text { Afrika } \\
\text { Cumhuriyet } \\
i\end{array}$ & $\begin{array}{l}\text { Cape } \\
\text { Town'un } \\
\text { Khayelitsha } \\
\text { Merkezi İş } \\
\text { Alanı }\end{array}$ & $\begin{array}{l}\text { Alan temelli } \\
\text { yaklaşım. } \\
\text { Sosyal, } \\
\text { ekonomik ve } \\
\text { fiziksel } \\
\text { kalkınma } \\
\text { hedefleri }\end{array}$ & $\begin{array}{l}\text { •1999, MİA } \\
\text { Gelişim planı } \\
\text { •2001, Ulusal } \\
\text { çapta başlatılan } \\
\text { Kentsel } \\
\text { Yenileme } \\
\text { Programı } \\
\text { (URP) } \\
\text { •Cape Town } \\
\text { Metropoliten } \\
\text { Mekânsal } \\
\text { Gelişim } \\
\text { çerçevesi } \\
\text { (MSDF) }\end{array}$ & $\begin{array}{l}\text { •Khayelitsha } \\
\text { Toplum Vakfi } \\
\text { tarafından mali } \\
\text { içerik kontrol } \\
\text { edilmiştir. } \\
\text { •İnşa edilen } \\
\text { ticaret merkezleri } \\
\text { projeye } \\
\text { finansman } \\
\text { desteği } \\
\text { sağlamıştır. }\end{array}$ & $\begin{array}{l}\text { - Alan temelli bir } \\
\text { yaklaşımla farklı } \\
\text { aktörlerin } \\
\text { entegrasyon ve } \\
\text { koordinasyonu } \\
\text { etkili şekilde } \\
\text { sağlanmıştır. } \\
\text { - Ekonomik } \\
\text { büyüme ve } \\
\text { istihdam artışı } \\
\text { gerçekleştirilmişti } \\
\text { r. }\end{array}$ \\
\hline
\end{tabular}


Tablo 1. (Devam).

\begin{tabular}{|c|c|c|c|c|c|c|}
\hline & Italya & $\begin{array}{l}\text { Umbria } \\
\text { Bölgesi } \\
\text { Tarihi Kent } \\
\text { Merkezi }\end{array}$ & $\begin{array}{l}\text { Kültürel çevre } \\
\text { ve tarihi } \\
\text { koruma. } \\
\text { Özel } \\
\text { girişimcinin } \\
\text { sınırlandırılması }\end{array}$ & $\begin{array}{l}\text { •2008 çıkarılan } \\
\text { kanunla tarihi } \\
\text { merkez için } \\
\text { normlar } \\
\text { belirlenmiştir. } \\
\text { •QSV: } \\
\text { İyileştirme } \\
\text { stratejik } \\
\text { belgesi } \\
\text { •ARP: } \\
\text { Öncelikli } \\
\text { dönüşüm } \\
\text { alanlarının } \\
\text { belirlenmesi }\end{array}$ & $\begin{array}{l}\text { - İmar hakkı } \\
\text { transferi } \\
\text { (yalnızca } \\
\text { dönüşüm } \\
\text { projelerinde } \\
\text { verilen ve tarihi } \\
\text { kent merkezi } \\
\text { dişarısında } \\
\text { kullanılan bir } \\
\text { hak) } \\
\text { Ve transferin } \\
\text { getirdiği bonus } \\
\text { hak }\end{array}$ & $\begin{array}{l}\text { - Maliyet avantajı } \\
\text { sağlayan bir } \\
\text { planlama aracı } \\
\text { uygulanmıştır. } \\
\text { - Özel } \\
\text { girişimcinin tarihi } \\
\text { kent merkezinde } \\
\text { etkinliği yeterli } \\
\text { seviyede } \\
\text { sınırlandırılmıştır. }\end{array}$ \\
\hline \multirow[b]{2}{*}{ Kentler } & Angola & $\begin{array}{l}\text { Luanda } \\
\text { Metropoliten } \\
\text { Alan1 }\end{array}$ & $\begin{array}{l}\text { Entegre ve } \\
\text { bütünleşik bir } \\
\text { yaklaşım. } \\
\text { Kamu } \\
\text { girişimleri, özel } \\
\text { yatırım } \\
\text { koşullarını } \\
\text { sağlamaktadır. }\end{array}$ & $\begin{array}{l}\text {-İhtiyaç ve } \\
\text { potansiyeller } \\
\text { belirlenmiştir. } \\
\text { - Kat1lım } \\
\text { modeli ve } \\
\text { Fayda maliyet } \\
\text { analizleri } \\
\text { •Dönüşüm } \\
\text { kriterleri } \\
\text {-Konut tipleri } \\
\text { (aile tipleri için } \\
\text { barnma } \\
\text { tipleri) } \\
\end{array}$ & $\begin{array}{l}\text {-Kamulaştırma } \\
\text {-Arazi } \\
\text { bankalarının } \\
\text { oluşturulması } \\
\text { - Ortaklık modeli } \\
\text { içeren hak } \\
\text { transferleri }\end{array}$ & $\begin{array}{l}\text { - Tüm paydaşlara } \\
\text { net roller } \\
\text { verilmiştir. } \\
\text { • Vergilendirme } \\
\text { avantajları } \\
\text { sağlayarak özel } \\
\text { sektörü yatırım } \\
\text { yapmaya teşvik } \\
\text { eden bir sistem } \\
\text { getirilmiştir. }\end{array}$ \\
\hline & Ingiltere & $\begin{array}{l}\text { Newcastle } \\
\text { Kentsel } \\
\text { Dönüşümü }\end{array}$ & $\begin{array}{l}\text { Toplum odaklı } \\
\text { yaklaşım. }\end{array}$ & $\begin{array}{l}\text { •1999, Going } \\
\text { for Growth } \\
\text { planı (2020 } \\
\text { yılını hedef } \\
\text { alan- ülke } \\
\text { çapında } \\
\text { kentsel } \\
\text { dönüşüm } \\
\text { stratejisi) } \\
\text { •Düşük gelirli, } \\
\text { düşük talep } \\
\text { gören konut } \\
\text { mahallelerinin } \\
\text { büyük ölçekte } \\
\text { yeniden } \\
\text { geliştirilmesi } \\
\text { ve bu bölgelere } \\
\text { daha varlıklı } \\
\text { bir nüfusun } \\
\text { getirilmesi için } \\
\text { öneriler } \\
\text { içermektedir. }\end{array}$ & $\begin{array}{l}\text { Özel sektör } \\
\text { yatırımı }\end{array}$ & $\begin{array}{l}\text { - Büyük ölçekli } \\
\text { konut gelişimi, } \\
\text { yatırım ve orta } \\
\text { gelirli aileleri } \\
\text { çekmiştir. } \\
\text { - İnsan odaklı ve } \\
\text { katılım bir süreç. } \\
\text { - Soylulaştırmaya } \\
\text { sebep olmuştur. }\end{array}$ \\
\hline
\end{tabular}

[Yazarlar tarafından oluşturulmuştur.]

Tablo 1'de yer alan tüm bu örnekler kentsel dönüşüm uygulamalarının kent bütününde düşünülerek irdelenmesi gereken önemli bir konu olduğunu göstermektedir. Cape Town'un Khayelitsha merkezi iş alanı ve Newcastle kentsel dönüşüm projesi, ulusal çapta gerçekleştirilen bir dönüşüm süreci ve planlama aşamasının bir parçası olarak değerlendirilmiştir. Johannesburg kent merkezi, Cape Town'un Khayelitsha merkezi iş alanı, Umbria bölgesi tarihi kent merkezi, Luanda örneği ve Newcastle kent bütününde yürütülen ya da kent bütünü ile eşgüdümlü düşünülen birer planlama içeriğine sahiptir. 
Planlama süreçleri yerel yönetim tarafından yürütülmüş, kamu girişimleri ile özel sektör yatırımları sağlanmıştır. Dönüşüm finansmanına yönelik uygulama araçlarında ortak noktalar içeren Umbria bölgesi ve Luanda metropoliten alanı dönüşüm projeleri imar hakkı transferleri ile gerçekleştirilmiştir. Xintiandi bölgesi tarihi kent merkezi ve Cape Town'un Khayelitsha merkezi iş alanı örneklerinde ticaret ve ofis alanlarının inşasının getirisi ile donatı alanları ve diğer kamusal alanların inşası desteklenmiştir. Güney Afrika Cumhuriyeti örnekleri Johannesburg kent merkezi ve Khayelitsha merkezi iş alanı dönüşümleri vergi ve oluşturulan vakıfla desteklenmiştir. Cape Town ve Şangay örnekleri kent merkezlerini içeren yapıları ile küresel ve ulusal düzeyde rekabet edilebilirliği hedeflemiştir. Süreç sonunda uygulama ile ciddi ekonomik büyüme, istihdam etkisi ve rekabeti yüksek alanlar olarak ülke ve dünya çapında önemli konuma erişmiştir.

Şangay Xintiandi projesinin uygulama sürecinde düzenleyici mekanizma olarak yasal düzenlemelere ihtiyaç duyulmuştur. Dönüşüme tüm paydaşların katılımı konusunda ise Newcastle, Luanda ve Johannesburg örneklerinde özellikle geniş ve başarılı süreçler işletilmiştir.

Dünyanın farklı ülkelerinden incelenen tüm bu örnekler, kentlerin değişen koşullar ve büyüme gibi sebeplerle problemli alanlara sahip olduğunu ortaya koymuştur. Bu alanlar kentin yaşanabilirliğini olumsuz etkilemeye başlamaktadır. $\mathrm{Bu}$ bağlamda kentsel dönüşüm problemli alanları esas alarak gerçekleştirilmiştir. Tablo 1'de özetlenen örnekler, tüm süreçleri kapsamlı olarak değerlendiren, rasyonel kararlar üretilen, tüm boyutları ile dönüşümü değerlendiren ve sorunlara çözüm üretebilen projelerin başarılı olabileceğini ortaya koymuştur.

Türkiye'de, çoğu projenin kapsamının belirlenmediği ve gerekli analiz sürecinin tamamlanmadığ gözlemlenmektedir. Planlama çerçevesinin oluşturulmasında kapsamlı bir içerik oluşturulmasında problemlerin varlığı dikkat çekmektedir. Uygulanan projelerin sosyal etkilerinin düşünülmeden gerçekleştirilmesi yeni problemlerin ortaya çıkmasına neden olmaktadır. Bu bağlamda sürecin öneminin ortaya konulması amaciyla örnek alan özelinde detaylı bir inceleme gerçekleştirilmiştir.

\section{Alan çalışması: Konya kentsel dönüşüm süreci deneyimleri}

$\mathrm{Bu}$ bölüm, kavramsal araştırmalardan elde edilen bilgiler çerçevesinde örnek proje alanına ait genel bilgilendirme ile kapsam belirleme, planlama, finansman ve uygulama olarak belirlenen kentsel dönüşüm sürecinin, Konya tarihi kent merkezi kentsel dönüşüm çalışmaları kapsamında nasıl gerçekleştiğini değerlendirmeyi hedeflemektedir. Öncelikle alana ilişkin genel bilgiler ve planlama sürecine yönelik değerlendirmeler yapılmıştır. Ardından örnek alan özelinde gerçekleştirilen kentsel dönüşüm süreci aşamalar halinde aktarılarak deneyimler aktarılmıştır.

\subsection{Konya tarihi kent merkezi mekânsal değişimi ve örneklem alanın belirlenmesi}

Makalenin örneklem alanı, Sultan I. Alâeddin Keykubat tarafından yaptırılmış dış kale surlarını referans alarak, Konya Kültür ve Tabiat Varlıklarını Koruma Kurulu'nca 01.06.2009 tarih ve 3038 sayılı kararı ile III. Derece Arkeolojik Sit Alanı olarak ilan edilen alan ve bu alanın mücavirinde yer alan kentsel sit alanlarını içeren 195 ha büyüklüğündeki Konya tarihi kent merkezidir (Şekil 1). Tarihi kent merkezinde tarihi bedesten çarşısı, camiler ve türbeler gibi önemli tarihi yapılar bulunmaktadır. Bu alan 
yaya ve araç trafiğinin, ticari faaliyetlerinin (geleneksel ve modern ticaret), resmî kurumların, finans sektörünün, eğitim alanlarının yoğun olduğu bir alandır. 1980'li ve 90'lı yıllara kadar hızlı gelişme bölgenin çok katlı apartmanlardan oluşan bir yapı stokuna dönüşmesine neden olmuştur. Konya tarihi kent merkezi içerisinde eski mahalle dokusu tamamıyla kaybolmuş, yoğun apartman yapılarının hâkim olduğu, fiziksel olarak yıpranmış, sosyal donatı ve teknik alt yapı açısından yetersiz ve yaşam kalitesinin oldukça düşük olduğu bir yerleşim alanı olmuştur. Kent bütününde apartmanlaşma hareketi ve artan nüfusa yönelik konut üretimi politikaları nedeni ile merkezde bulunan ve yap1 kalitesi yeni yapılara nazaran sağlıklı yaşam koşullarını barındırmayan, eskimiş, köhne yapılar ve kentsel cazibesini yitiren yapılar el değiştirmiş; göç ile dışarıdan gelen nüfusun da barınma alanı haline gelmiştir.

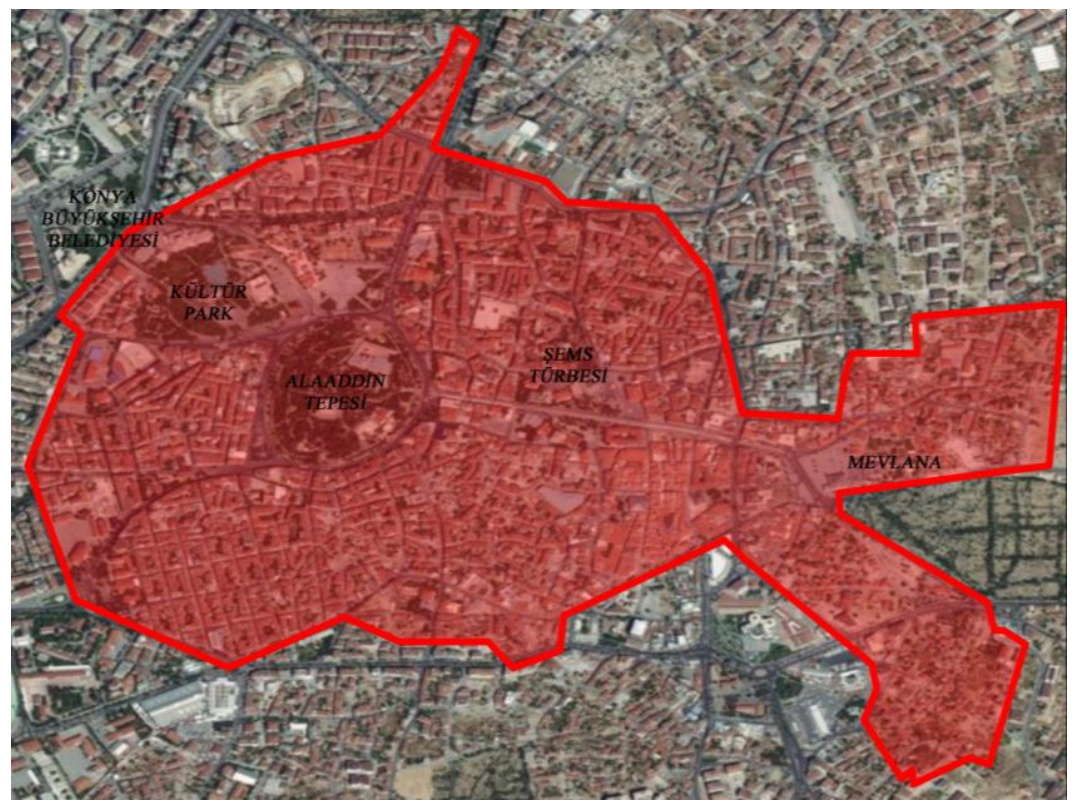

Şekil 1. Örneklem alan-Konya tarihi kent merkezi sınırları [Yazarlar tarafından oluşturulmuştur].

2000'li yıllarda yaşanan tüketim eğiliminin hızlanması ve konut ihtiyacındaki değişmeler bölgede bulunan yapıların tekrar el değiştirerek, alt gelir grubuna yönelik barınma ya da alt-orta grubun yatırım aracı işleviyle kiralama alanı olarak karşımıza çıkmaktadır. Bu durum mahalle sosyal yapısında büyük değişmelere neden olmuş ve alt gelir grubu ile çeşitli yabancı uyrukluların sığınma alanı haline gelmiştir [16].

\subsection{Konya tarihi kent merkezi kentsel dönüşüm sürecinin analizi ve bulgular}

Konya tarihi kent merkezinin dönüşüm süreci kapsam, planlama çerçevesi, finansal araçlar ve uygulama ana başlıklarında kent bütününde değerlendirilmiştir.

\subsubsection{Kentsel dönüşüm projesi kapsam belirleme aşaması}

Kapsam belirleme aşaması, kentsel dönüşüm projesinin vizyonu-amac1, kentin-alanın bölgesel ve küresel konumunun analiz edilmesi, değişim ve müdahaleler için firsatlar ve engeller kapsamında ele alınmıştır.

Konya tarihi kent merkezi dönüşüm vizyonu;

Konya tarihi kent merkezi koruma odaklı dönüşüm stratejisi vizyonunun belirlenmesi, mevcut durum etkilerinin analiz ve sentezi, planlama ve tasarım, öncelikli alanların 
belirlenmesi, finansal stratejilerin belirlenmesi, rezerv alanların belirlenmesi, etaplamaların yapılması ile gerçekleştirilmiştir (Şekil 2).

Konya tarihi kent merkezi dönüşüm vizyonu, Konya'yı diğer kentlerden farklı kılan değerlerin tanıtılmasını, öne çıkarılmasını sağlayarak kentin turizm potansiyelinin artırılmasıdır. Kenti diğer kentlerden farklı kılan Mevlâna kenti, dini ve kültürel değerler kenti, Anadolu Türk varlığının kurucu kenti gibi özelliklerinin tanıtılarak, kentteki konaklama sürelerini uzatacak fiziki düzenlemelerle, tarihi merkezin ticari cazibesinin artırılması hedeflenmektedir. Tarihi kent merkezindeki dönüşüme bağlı yapılacak fiziki düzenlemelerle, bir taraftan tarihi kent merkezinde özellikle tarihi yapıların çevresinde turist sirkülasyonunun ve ticaretin artırılması sağlanırken, diğer taraftan da tarihi kent merkezinde ana caddelerin arkasında Cumhuriyet Dönemi sonrasında yapılan köhnemiş, sosyal ve teknik altyapı açısından yetersiz alanların rehabilitasyonunu sağlamak amaçlanmıştır.

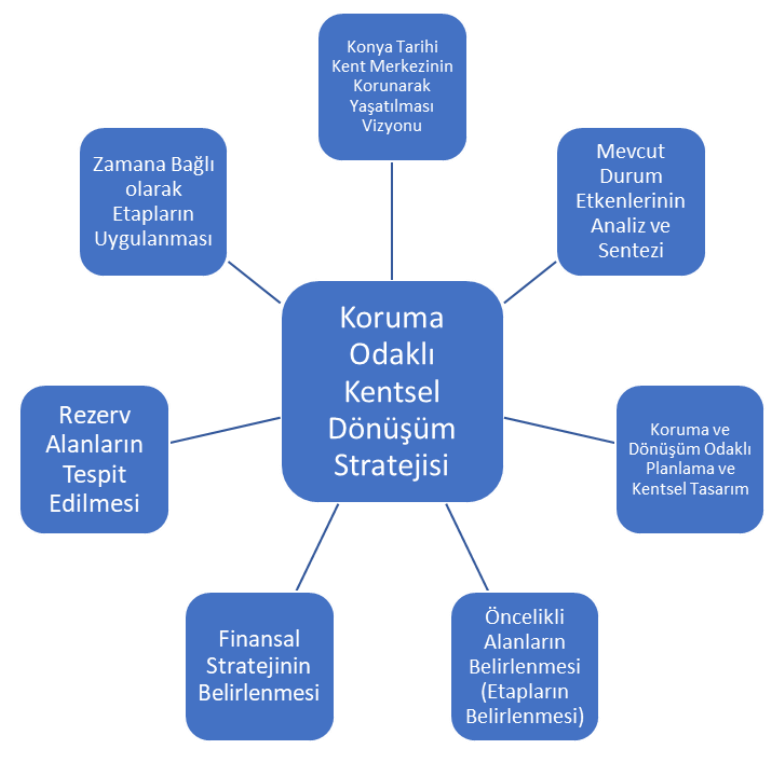

Şekil 2. Konya tarihi kent merkezi koruma odaklı kentsel dönüşüm stratejisi [17].

Kentin bölgesel ve küresel konumunun analiz edilmesi

Türkiye'de ziyaretçi sayıları açısından bakıldığında, Konya Mevlâna Müzesi, Ayasofya ve Topkap1 müzelerinden sonra en çok ziyaret edilen 3. müzesi olması, toplam konaklama ve konaklayan turistlerin geceleme sayılarında artan bir eğilim nedeniyle de turizmde önemli gelişmeler yaşanmaya başlamıştır. Kültür ve Turizm Bakanlığı tarafindan hazırlanan Türkiye Turizm Stratejisi Kavramsal Eylem Planı'nda Konya kültür ve inanç turizmi odaklı yerleşmeler arasında yer almıştır.

Konya, tarımsal üretim ve imalat sektörü odaklı sanayi altyapısı, doğal ve kültürel miras değerleri ile Türkiye'nin ulusal-uluslararası düzeyde tarım, sanayi ve turizm merkezidir. Bu yönleri ile farklı ölçeklerde planlama çalışmaları kapsamında özel olarak ele alınması gereken bir kenttir [18].

Değişim ve müdahaleler için firsatlar ve engeller

Konya'yı diğer kentlerden farklı kılarak öne çıkaran faktörlerden birisi inanç ve kültür turizmidir. Tarihi kent merkezinde yer alan Mevlâna Türbesi ve diğer tarihi yapılarla birlikte sahip olduğu turizm potansiyeli, ticaret hacminin artmasına neden olmaktadır. 
Son yıllarda tarihi kent merkezinin sosyal ve demografik yapısının değişime uğraması, güvenlik problemlerinin ortaya çıkması, fiziki standartlarının kötüleşmesi, köhneleşmesi ve toplumda dönüşüme yönelik taleplerin artması ile dönüşüm firsatı barındırmaktadır. Asayiş sorunları ve sosyal donatıların yetersizlikleri gayrimenkul değerlerin azalmasına neden olurken, dönüşümün finansal boyutu yönünden katkı sağlamaktadır.

Koruma alanlarında, mülkiyet hakkının getirdiği mülkü kullanmak, mülkten yararlanmak ve tasarruf etmek öğeleri koruma amacı ile kısıtlanabilmekte, ancak bu kısıtlama bir şekilde telafi edilemediği durumda koruma amacı yeterince gerçekleştirilememektedir. Ayrıca, belirlenen koruma alanları her geçen gün artan biçimde yapılaşma baskısına maruz kalmaktadır. Bu baskılar ile birlikte, bu alanların korunması güçleşmekte, çoğu değerler yitirilme tehlikesi ile karşı karşıya kalmaktadır [19].

Tarihi alanların gayrimenkul odaklı dönüşümü sonucu, özgün değerler yok edilerek yerlerine; 'tarihi gibi görünen' yapılar ve mekânlar inşa edilmektedir. Bu süreçte, çokkültürlülük korunamamaktadır. Mekânsal sorunları çözmek amacıyla gerçekleştirilen aceleci ve toptancı planlama yaklaşımları, özgün yaşam alanlarının ve kimliklerinin yok olmasına neden olabilmektedir [20]. Bu duruma neden olan en önemli etken dönüşüm için yeterli finansal araçların bulunmamasıdır.

Bu çalışmada ele alınan proje alanında, tarihi kent merkezinde 2009 yılında ilan edilmiş olan 3.derece arkeolojik sit alanı kararıyla birlikte, 2863 sayılı Kültür ve Tabiat Varlıklarını Koruma Kanunu gereğince koruma amaçlı imar planlarının yapılması yasal bir zorunluk haline gelmiştir. Bu yasal zorunlukla birlikte Tarihi Kent Merkezinin Dönüşümü Konya Çevre Düzeni Planı'nda belirlenen stratejilerle birlikte değerlendirilerek koruma odaklı planlama yaklaşımı ortaya çıkmıştır.

\subsubsection{Kentsel dönüşüm projesi sürecinin planlama aşaması}

Planlama aşamasına ilişkin, fizibilite çalışmaları, fiziksel, ekonomik, sosyal ve mekânsal unsurlar ve analizler, planlamanın içeriği, planlama süreci, planlama çerçevesi, plan stratejileri, dönüşüm öncelikli bölgeler ve uygulama etaplarının belirlenmesi, aktörlerin süreci etkileme durumu gibi konular ele alınmıştır.

Fiziksel, sosyal, ekonomik mekânsal unsurlar ve analizler

Tarihi yapılar ve turizm odaklart: Konya tarihi kent merkezinde, 48 cami-mescid, 13 türbe, 13 medrese-külliye, 3 han, 3 hamam, 1 kilise, 12 kamu yapısı, 144 konut, 26 dükkân, 49 çeşme olmak üzere toplamda 312 tescilli taşınmaz bulunmaktadır. Bunlar arasında Mevlâna Türbe ve Müzesi, Şems-i Tebrizi Camii ve Türbesi, Alâeddin Camii, Karatay Medresesi, İnce Minareli Medrese, Beyhekim Cami, Sırçalı Medrese, Sahip Ata Medresesi ve Külliyesi gibi eserler bulunmaktadır.

Tarihi kent merkezinin büyük bir çoğunluğu 3. derece arkeolojik alan sınırını da belirleyen dış surlardır. Dış surlar, Alâeddin Keykubat tarafından yaptırılmış olup 12 kapıdan oluşmakta genişliği $3 \mathrm{~m}$ çevresi $6 \mathrm{~km}$ kadardır. Dış surların büyük bir kısmı zamanla toprak altında kalmış yüzeyde kalan kısımları ise tahrip edilmiştir. Planlama çalışmalarına başlamadan önce bilimsel bir rapor eşliğinde jeoradar çalışması yapılarak yeri tam olarak belirlenmeye çalışılmıştır [21].

Koruma odaklı kentsel dönüşüm ve yenilemeyi esas alan planlama süreçlerinde, mekânsal planlamanın kendine özgü standart fizibilite çalışmaları (kat adetleri, bina cinsi, 
bina durumu, bina yaşı, arazi kullanım durumu vb.) yeterli olmamaktadır. Bu çalışmada tarihi kent merkezi aşağıdaki başlıklarda analiz edilerek, öncelikli dönüşümün gerekliliği ve nereden başlaması gerektiği test edilmiştir. Bu amaçla tarihi kent merkezi bölgelere ayrılarak dönüşümde öncelikli bölgeler tespit edilmesi sağlanmıştır.

Koruma odaklı kentsel dönüşüme esas alınan etkenlerde tarihi yapı varlığı, yapıların nitelikleri ve fiziksel görünümü, turizm odağı varlığı, erişilebilirlik potansiyeli, arkeolojik değer varlığı mevcut yapı yoğunluğu, mevcut açık alan kullanımı, teknik altyapı durumu, suç potansiyeli, arazi değerleri gibi etmenler tanımlanarak tarihi kent merkezinin, kent içinde öne çıkan yönleri ve tarihi kent merkezinde hangi bölgelerin öncelikli dönüşüm alanı olduğu tespit edilmiştir. Bu çalışmayla kentsel dönüşümde öncelikli finans ayrılması gereken yerler ile süreç içinde değişim öngörülen yerlerin ayrışmasının sağlanması amaçlanmıştır.

Planlama alanında mevcut durumu ortaya koymak ve ortaya çıkan sonuçları değerlendirmek amaciyla Konya Kent Bilgi Sistemi veri tabanında bulunan tablolar yardımıyla çeşitli analizler yapılmıştır.

Bina ve sosyal doku analizinde; planlama alanı içerisinde fiziksel durumu orta ve harap olan binaların oranı \%77 iken, iyi durumda alan binaların oranının \%23 olduğu görülmektedir (Şekil 3).

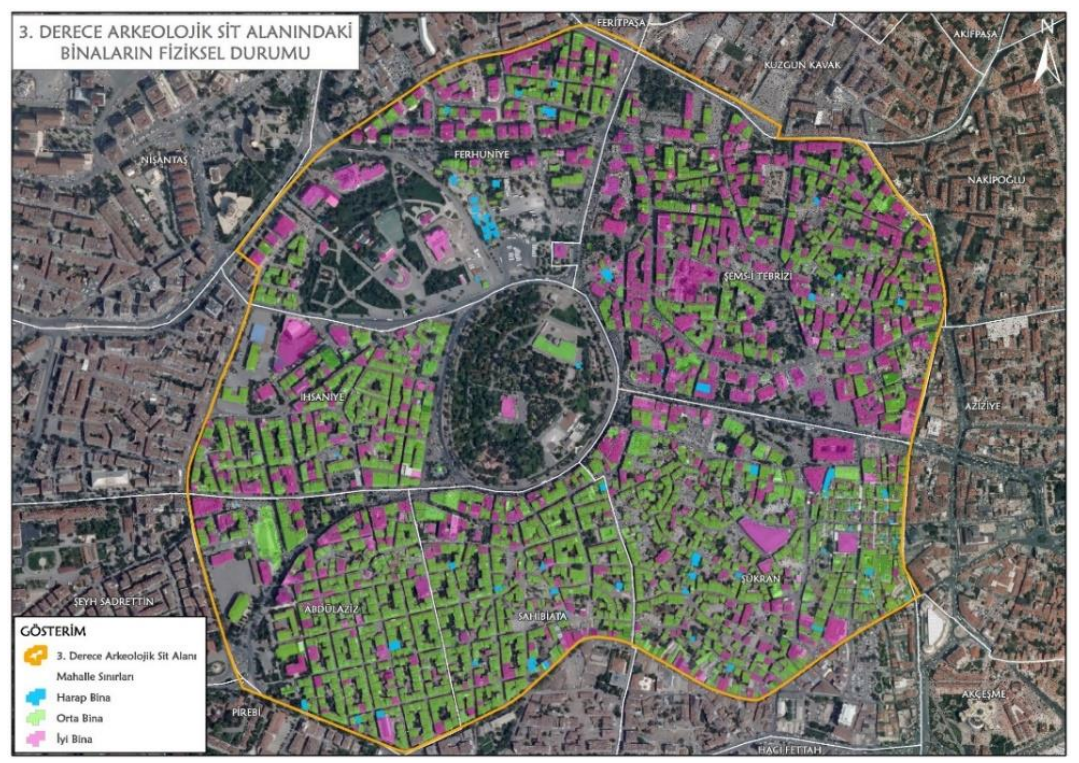

Şekil 3. Sit alanındaki yapıların fiziksel durumu [17].

Sosyal doku ve suç analizlerinde; Konya Büyükşehir Belediyesi ve Konya İl Emniyet Müdürlügü̈nün ortak iş birliği protokolü ile oluşturulmuş CBS veri tabanı kullanılmıştır. $\mathrm{Bu}$ verilere göre kent merkezi bütünü içinde işlenen suçların büyük bir çoğunluğunun tarihi kent merkezi alanında olduğu görülmektedir (Şekil 4a). Sosyal doku analizlerinde Konya Büyükşehir Belediyesi'nin kent merkezinde yaptığı sosyal doku anketleri kullanılmıştır. Tarihi kent merkezinin kent bölgelerinden ayrıştığı sosyal yardım alma, düşük gelir durumu, kiracı yoğunluğu analizleriyle de doğrulanmaktadır (Şekil 4b). Konya'da asayiş suçlarının dağılımı, arazi kullanım ile ilişkilendirildiğinde, suç miktarlarının merkezden çeperlere doğru düşüş gösterdiği tespit edilmiştir (Şekil 5 a, b) $[22]$. 


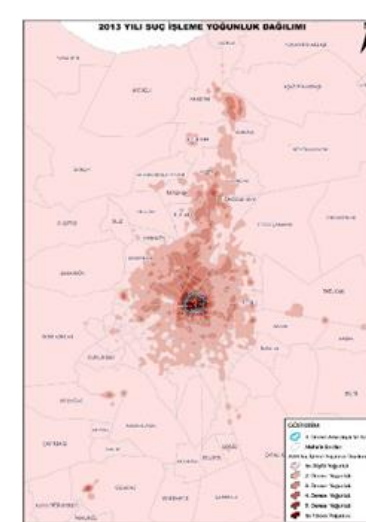

a

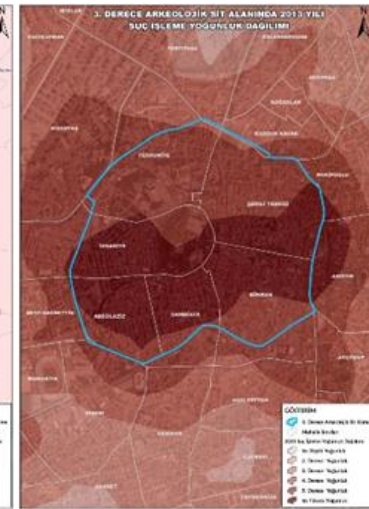

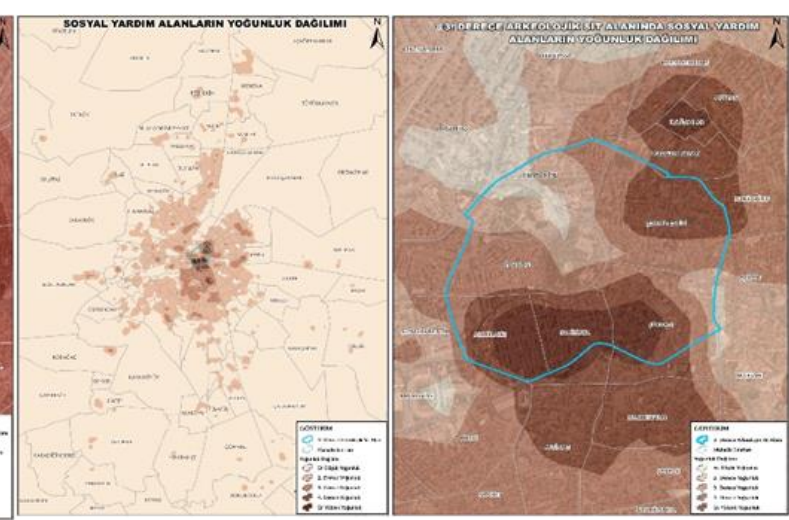

b

Şekil 4. Kent bütününde ve tarihi kent merkezi içinde a-suç ve b-sosyal yardım yoğunluk analizi [17].

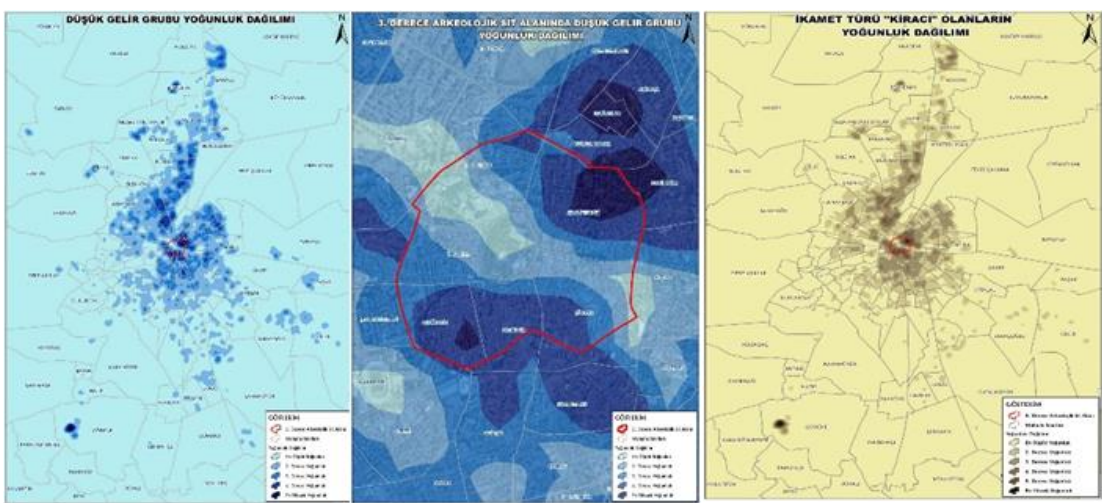

a

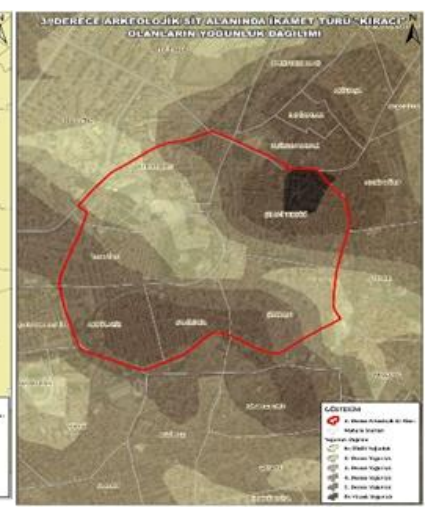

b

Şekil 5. Kent bütününde ve tarihi kent merkezi içinde a-düşük gelir durumu ve bkiracıların yoğunluk analizi [17].

Ulaşım analizi; kent merkezinde büyüme ivmesinin artması, trafik yoğunluğunu da artırmaktadır. Çalışma alanında mevcut yol ve kaldırımların dar, kullanışsız ve sorunlu olması, hem taşıt trafiğini, hem de yaya hareketlerini sınırlandırmaktadır. Binaların ön bahçesiz yapılaşması nedeni ile kendilerine ait otopark alanlarının ve bölge otoparklarının bulunmaması kaldırımlarda park yapan araçların oluşmasına ve trafik problemi yaşanmasına neden olmaktadır.

Yapılaşma sistemi analizi; alanda yapı ön bahçe mesafelerinin bırakılmadığı, çoğunlukla cepheden yapılaşmanın oluştuğu gözlemlenmiştir. Özellikle konut harici kullanımlara dönüştürülen binaların Yangından Korunması Hakkında Yönetmelik hükümlerine uygun olmadığı ayrıca bölgede düzensiz ve çarpık yapılaşmanın olduğu görülmektedir. Bölge kent estetiği ve yaşam koşulları açısından da olumsuzluklar barındırmaktadır. Kaçak yapılan kat ve teras kapatmaları kentin en önemli turizm ve ticaret aksında görüntü kirliliği oluşturmaktadır. Tarihi dokuda yer alan yapılar korunarak işlev kazandırmada potansiyel olmaktadır. Ancak yapıların fiziksel ve sosyal çevresi ile uyum problemi bulunmakta tarihi değere sahip tescilli yapılar niteliksiz binalar arasında baskı altında ve işlevsiz durumda kalmaktadır.

Mevcut planın analizi; 1/100.000 ölçekli Çevre Düzeni Planı'nda merkezi iş alanına (MİA) isabet etmektedir. Plan uygulama hükümlerine göre MİA; yönetim, turizm, sosyal 
kültürel ve ticari amaçlı yapılar için ayrılmış kentin merkezinde kalan bölgedir. Konya Büyükşehir Belediye Meclisi'nce 2015 yılında onaylanan Konya ili 1/100.000 Çevre Düzeni Planı Uygulama Hükümlerinin Özel Hükümler Bölümünde, il genelinde stratejik planlama kararları alınmıştır. Tarihi kent merkezi ile ilgili alınan stratejik karar;

\section{“4.1.19. Stratejik Karar-19 (ST-19)}

'Konya Tarihi Kent Merkezi Yenilemesi: Konya geleneksel kent merkezinde, '3. derece arkeolojik sit've 'kentsel sit' olarak koruma altına alınmıs olan alanlar ile bu alanların çevresinde belirlenecek 'etkileme geçiş alanlarında' kalan alanların koruma ilkeleri çerçevesinde yenilenmesi ve geleneksel doku ile uyumlu dönüşümünün sağlanmasına yönelik kararlar alt bölge planında belirlenecektir." şeklindedir. Bu karar çerçevesinde üst ölçekli plan kararlarına da uygun olacak şekilde dönüşüm alanı olarak belirlenmiştir.

Koruma amaçlı imar planı genel çerçevesi

Tarihi kent merkezinin büyük bir kısmının 3.derece arkeolojik sit alanı olması ve alan içinde var olan kültür varlıklarının yaşatılmasına yönelik dönüşüm projesinde planlama yaklaşımının temelinde koruma yaklaşımı bulunmaktadır. Bozulan kent dokusu içinde özellikle tescilli kültür varlıkları çevrelerinde belirlenen odak alanların, turizm sirkülasyonuna açılması sonrasında oluşan ticari hareketle cazibe alanları haline getirilmesi, koruma amaçlı plan kararları ile mevcut yoğunluk ve kat adetleri düşürülen yapılaşma koşullarına uygun olarak yenileme veya dönüşüm projelerinin uygulanmasının sağlanması genel planlama çerçevesini oluşturmaktadır.

Tarihi kent merkezinde yapılan koruma amaçlı plan stratejileri;

1.Tarihi kent merkezi içinde birbirleriyle ilişkilendirilen kültür akslarının oluşturulması,

2. Tarihi kent merkezinde bulunan organik ve ızgara kent dokuları korunarak diğer alanların bu tarihi parsel dokusuna uygun olarak yapılaşmasının sağlanması,

3. Tarihi anıtsal ve sivil mimarlık örnekleri, oluşturulan Kültür Aksının ana omurgası olup bu alanlar aktif yeşil alan ve meydanlar ile desteklenerek Tarihe Saygı konseptinin oluşturulmasi,

4. Kültürel akslar içinde özellikle birinci derece korunacak yapı ve çevresindeki alanların sosyal ve kültürel merkezler haline getirilerek Müze Kent temasının üretilmesi,

5.Tarihi kent merkezi yakın çevresinde ve Mevlâna Müzesi ile ilişkisi olan Kentsel alanlar genel bir etkileme geçiş alanı anlayışı ile kültür merkezi, müze, rekreasyon ve kentsel dönüşüm projeleri ile desteklenerek yeni kent dokusu ile tarihi doku arasında yumuşak bir geçişin sağlanmasıdır [16].

Tarihi kent merkezinde toplam yapı yoğunluk miktarı mevcut yapı yoğunluğuna göre \%39 oranında azaltılmıştır. Açık alan kullanımları artırılırken, dönüşüm stratejisi nedeniyle azaltılan yapı yoğunluğu ile birlikte mevcut konut kullanımı azaltılmış ticari kullanım artırılmıştır (Şekil 6). Dönüşümün gelecekte normatif bir yaklaşım nedeniyle aksaması ve plan tadilatlarına yol açmaması amacıyla plan notlarıyla konut-ticaret-turizm karma kullanım fonksiyonlarının birbirine dönüşümüne olanak sağlanmıştır. 


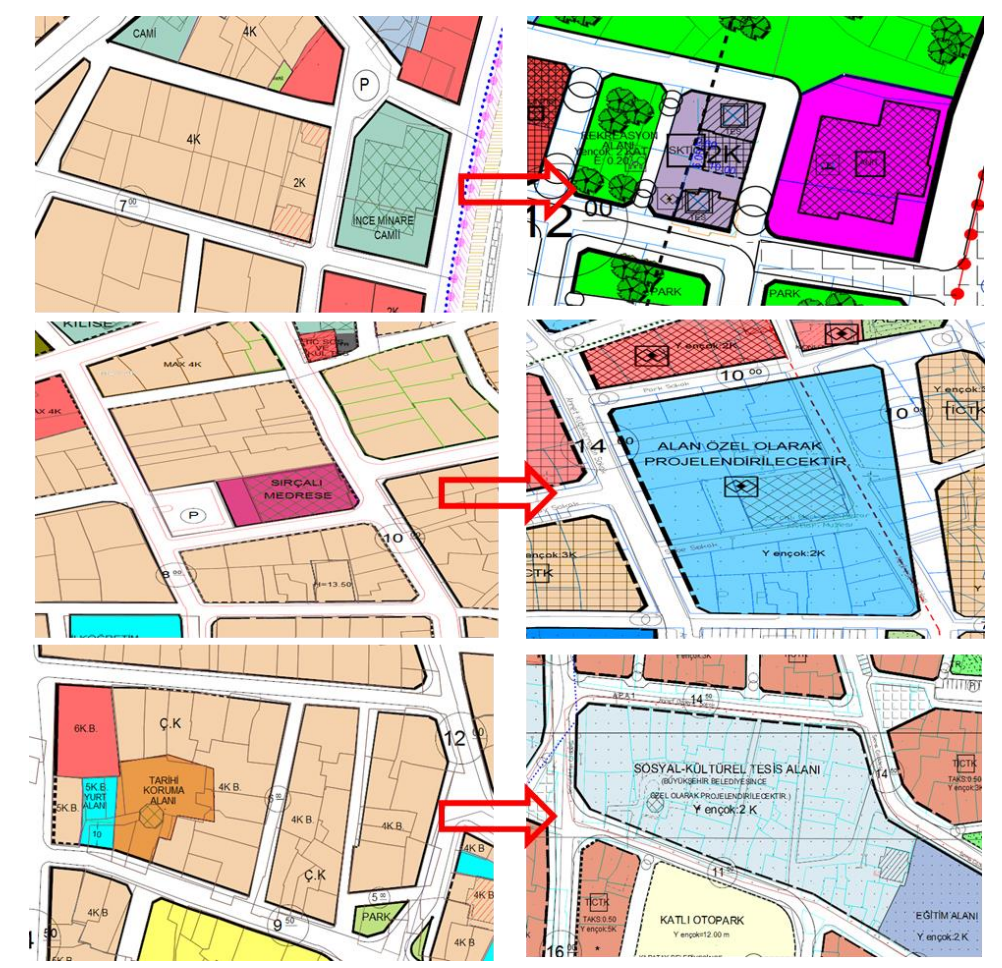

Şekil 6. Tarihi kent merkezinde 1.grup yapılar etrafında plan kararlarının değişimi [17].

\section{Dönüşüm öncelikli bölgeler ve uygulama etaplarının belirlenmesi}

Bu kapsamda öncelikle dönüşüme etken olan faktörlerin tarihi alan içinde hangilerinin daha fazla farklılık gösterdiğinin tespiti amacıyla her bölgede bir turizm odağı olması esasına göre tarihi kent merkezi 7 bölgeye ayrılmıştır. CBS platformunda koruma odaklı dönüşüme etken değerlerin (Şekil 7) mekânsal analizlerle elde edilmiş rasterlar üzerinden dönüştürülen sınıflama değerleri puanlama şeklinde bölgelere tanımlanarak öncelikli bölgeler belirlenmiştir (Şekil 8). Bu aşamadan sonra koruma odaklı dönüşüm stratejisi gereği etaplama aşamasına geçilmiştir. Öncelikli bölgeler ve uygulama etap haritaları koruma amaçlı imar planın uygulanması ve dönüşümün finansmanına yönelik çalışmalara temel altlık oluşturmuştur.

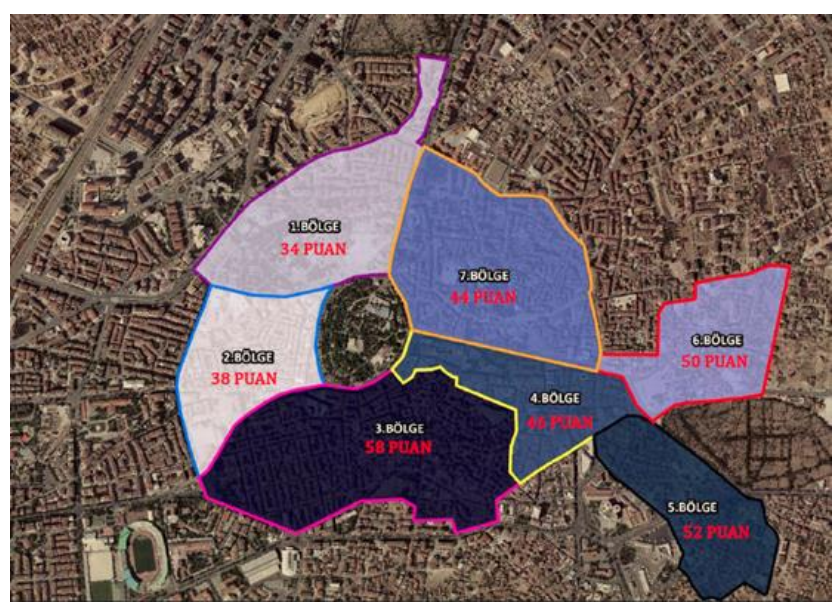

Şekil 7. Tarihi kent merkezi bölgeleme [17]. 


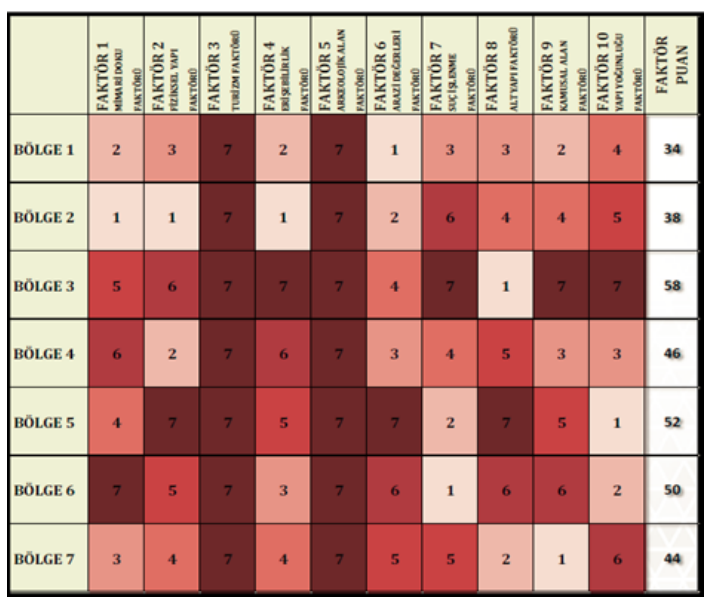

Şekil 8. Dönüşüme etken faktörlerin mekânsal analiz sınıflandırma verilerinin puanlanmas1 [17]

1. Bölge Kültür Park ve çevresindeki alandır. Bu alanın turizm odak noktası Kılıçaslan Meydanı ve Kültür Park'tır. Öncelik puanı 34'dür.

2. Bölge İnceli Minareli Medrese ve çevresindeki bölgedir. Bu bölge içinde Atatürk Evi - Bey Hekim Camii ve İnce Minareli Medrese arasında turizm aksı oluşturulmuş, bu aks sosyal donatılar ve açık alan kullanımını ihtiva edecek plan müdahaleleri yapılmıştır. Odak nokta İnce Minareli Medrese'dir. Öncelik puanı 38'dir.

3. Bölge Alâeddin - Sırçalı Medrese - Sahip Ata Camii Aksı ve çevresinde 1947 yılında oluşturulmuş, gridal planlama örneği taşıyan Abdülaziz Mahallesi bulunmaktadır. Ayrıca alan içinde Dış Kale surları yüzeye çok yakın geçmekte bir kısmı yüzeyde gözükmektedir. Odak noktası Sırçalı Medrese'dir. Öncelik puanı 58'dir.

4. Bölge Alâeddin Tepesi- Mevlâna Caddesi ve tarihi bedesteni içine alan kentsel sit statüsüne sahip bölgedir. Turizm odak noktası bedestendir. Öncelik puanı 46'dır.

5. Bölge Akçeşme Mahallesi ve çevresindeki kentsel sit statüsündeki bölgedir. Turizm odak noktası korunan sokak dokusu bulunan yerlerdir. Öncelik puanı 52'dir.

6. Bölge Mevlâna Dergâhı ve çevresidir. Odak nokta Mevlâna Dergâhı'dır. Öncelik puanı 50 'dir.

7. Bölge KTUN Mimarlık ve Tasarım Fak. - Mevlâna Evi - Şems Türbesi - Şerafettin Cami aksı ve çevresindeki bölgedir. Turizm odağı Mevlâna Evi ve Şems Türbesi'dir. Öncelik puanı 44'dür.

Kültür-turizm aksı olarak da belirlen 1. etap uygulama aşaması genel olarak kamulaştırma çalışmalarını, sonrasında ise bu alanlar üzerinde odak alanlar etrafında (tescilli 1. grup yapı) turizm etkinliklerinin yapılacağı sosyal ve kültürel donatı alanlarını ve açık alan kullanımlarının yapılmasını içermektedir. 1. etap içinde her bölgenin belirli kısımlarını dâhil edecek şekilde aşamalara ayrılmıştır (Şekil 9). Etabın gerçekleşmesi ile oluşturulacak turizm hareketi 1. etap çevresindeki 2. etap alanlarında ticaretin cazibesini artırarak zaman içinde koruma amaçlı imar plan kararları doğrultusunda kendiliğinden ve yerinde dönüşüme neden olacak etkiyi yaratacağı düşünülmektedir. 2.etap dönüşüm çalışmaları 1.etabın tamamlanması sonrasında başlatılacak olup birbirini takip eden üç uygulama senaryosu ile işlemler yürütülecektir. 


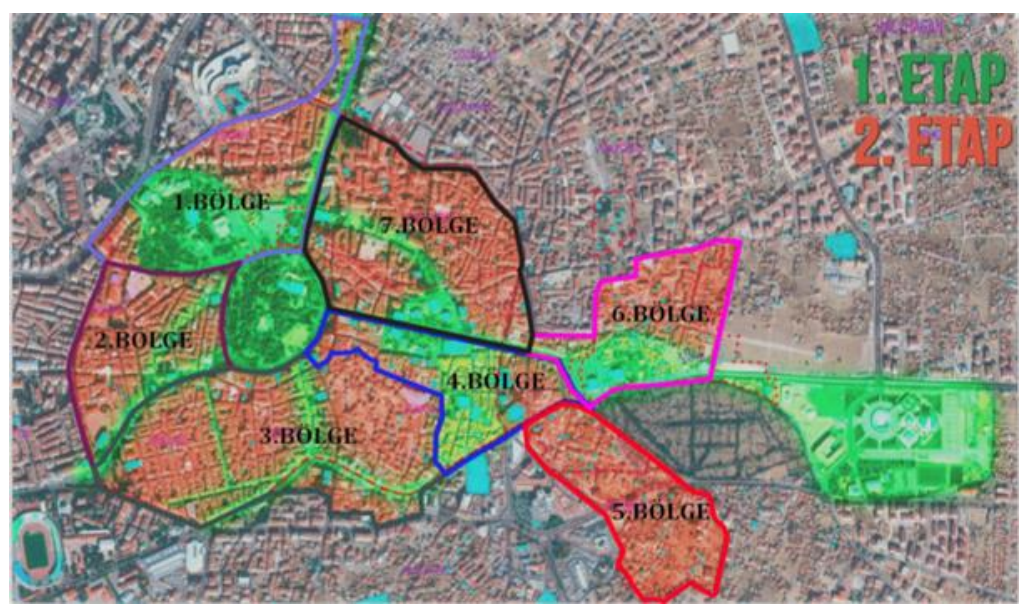

Şekil 9. Dönüşüm uygulama etapları [17].

Kültür-turizm aksı (1.etap) dışında kalan alanlarda (2.etap) koruma amaçlı imar planı genel stratejisinin gerektirdiği yoğunluk değerinin azalması ve kat adedinin düşmesine bağlı olarak dönüşümün finansal nedenlerle gerçekleşmeme riskini ortadan kaldırmak amacıyla, koruma amaçlı imar planında;

Mümkün olduğunca yapı taban alanı değerinin artırılarak yatayda büyüme sağlanması ve kat adedi artırılmadan eski yapı yoğunluk değerleri aşılmadan bir miktar tolere edilmesi sağlanmış, yeni yapılaşmaya gidilecek adalara planda belirlenen fonksiyonlarda karma kullanım tanımı yapılarak (karma kullanımın getirdiği sorunların önlemlerini plan uygulama hükümlerinde belirlemek kaydiyla) dönüşümün turizm-ticaret ve konut kullanımlarının süreç içinde piyasada daha fazla karşılık bulabilecek herhangi biriyle olması hedeflenmiştir.

Aktörlerin süreci etkileme durumu:

Koruma amaçlı imar planı onay aşamasına gelinmeden önce bölgede 2863 sayılı Kanun gereğince yetkili olan Kültür Varlıklarını Koruma Kurulu'na planlama yaklaşımı anlatılmış önerileri alınmıştır. Dış kale surları ve tarihi kent merkezi konusunda arkeolojik ve sanat tarihi araştırma raporlarıyla planlamanın desteklenmesi talep edilmiştir. Plana uygun görüş verilmesi amacıyla Büyükşehir Belediye Meclisi tarafından yetkilendirilen İmar ve Bayındırlık Komisyonlarınca tarihi kent merkezinde planlama yaklaşımı anlatılmıştır. Planın büyük kamulaştırmalar gereken kısımlarının Çevre ve Şehircilik Bakanlığı'nca sağlanacak rezerv alanlardan finanse edilecek olması nedeniyle planlama yaklaşımı kabul görmüştür.

$\mathrm{Bu}$ süreçte ilçe belediyelerinin ve meclis üyelerinin uygulama konusunda tereddütleri olmuş, bölgeye koruma odaklı yaklaşım yerine, gelişme alanlarında izlenen yöntemlere benzer planlama yaklaşımına gidilmesine yönelik tartışmalar yaşanmıştır. Bölgenin dönüşümünün yoğunluk vermeden sağlanmasının mümkün olmadığını belirten görüş mevcut yerleşimde korunması gereken bir unsur olmadığını çöküntü haline gelmiş yapı yığınlarının ancak tamamen yıkılıp yoğunluk artışı sağlanarak yeniden yapılaşması ile dönüşüm gerçekleşeceği tezini öne sürmüştür. Konya Kültür Varlıklarını Koruma Kurulu'nun katkıları ve müdahaleleri ile imar planları etaplar halinde askıya çıkarılmış ve yasal itirazların değerlendirilmeleri sonucunda kesinleşerek uygulama aşamasına gelinmiştir. Vatandaş itirazlarının çoğunluğu özellikle doğrudan kamulaştırma alanlarından gelmiş, bu alanların değerinin belediye tarafından karşılanması veya başka 
alanlardan daire verilmesi üzerine olmuştur. Diğer bir itiraz ise planda belirlenen yapılaşma yoğunluklarıyla yeni yapılaşmaya gidilemeyeceğine yönelik olmuştur.

\subsubsection{Kentsel dönüşüm projesi finansman aşamast}

Kentsel dönüşüm projesi için finansman modellerinin belirlenmesi sürecinde; belediyenin (etki ücretleri, özel değerlendirmeler gibi) doğrudan finansman yardımına yönelik finansal araçları ile teşvikler, imar, arazi kullanımı yönetmelikleri ve imar hakkı transferleri gibi düzenleyici araçlar değerlendirilmiştir.

Kültürel ve doğal miras kavramlarının dünya genelinde ve Avrupa Birliği sürecinde öneminin artması, bu alanların modern yaşam alanlarıyla bütünleştirilerek yaşatılmasına önem atfetmektedir. Serbest girişimcinin, özel sektör yatırımlarının sürekli desteklendiği devlet politikası ile bu alanların kullanımının, mülkiyetinin, nasıl olacağı, düzenlemelerde, uygulamalarda, rantı ve mülkiyet hakkını yönlendirmede hangi kurumlarının yetkili olacağıyla ilgili yeni yasal düzenlemeler yapılmıştır [23]. Bu aşamada, Konya tarihi kent merkezi dönüşüm projesinde finansal olanakları yönlendiren/sınırlandıran yasal mevzuat kısaca ele alınmıştır.

\section{Sayılı Kanun (Afet Riski Altındaki Alanların Dönüştürülmesi Hakkında Kanun)}

Kanun içeriğinde, Çevre ve Şehircilik Bakanlığı'na risk alanı tanımlamaya yönelik yetkiler verildiği gibi riskli alan ilan edilmesini veya riskli alan ilan edilemeden rezerv alan belirleyebilmeye de olanak sağlamaktadır. Kanun, Çevre ve Şehircilik Bakanlığı'na, riskli alanlarda uygulama yapacak belediyelere rezerv alanları bedelsiz devredebilme hakkı vermiştir. Böylelikle rezerv alanlar imar hakkı transferi ve finans aracı olarak kullanabilecek hale gelmiştir. Türkiye' de korunan alanların koruma ilkeleri çerçevesinde yenilenmesi için finans amaçlı rezerv alan belirleyebilmesine olanak sağlayan doğrudan amaca yönelik bir kanun bulunmamaktadır. 6306 sayılı Kanun, korunan alanlarını riskli alan olarak kabul etmemekle birlikte imar planına aykırılık teşkil eden alanların varlığını dikkate alarak rezerv alan belirleyebilmeyi de mümkün kılmaktadır. Kanun riskli alan içinde kentsel dönüşüm kanununa benzer teşvikler içermekle birlikte binaları yıkılan vatandaşlara kira yardımı yapılmasını içermektedir.

\section{Sayılı Kanun (Kültür ve Tabiat Varlıklarını Koruma Kanunu)}

Kanun'un 17/c maddesi korunan alan içinde yapılaşmaları kısıtlanan tescilli yapılar dâhil koruma alanı içinde yer alan mülkiyetlerin imar hakkının aktarım alanı belirlenen alanlara transferine yönelik hükümler içermektedir. Kanun tescilli kültür varlığının restorasyonuna yönelik mal sahiplerine mali destek verilmesini de mümkün kılmaktadır. Kanun ile SPK lisanslı firmalar tarafından korunan alan içinde planla yapılaşmaları kısıtlanan parsellerdeki transfer edilecek hak miktarının belirlemesi sağlanmaktadır. Belediye bu hak miktarlarını transfer edip ilgili aktarım arazisinde (rezerv alan) ruhsat vererek yapılaşmayı sağlama konusunda görevli kılınmıştır.

Konya tarihi kent merkezinin dönüşümüne yönelik planlama çalışmasının uygulanması amacıyla 2863 sayılı Kanun'da tarif edilen aktarım alanlarının, 6306 sayılı Kanun'da tarif edilen rezerv alanların büyükşehir belediyesine devri sağlanarak hem finansal araç sağlanmış hem de hak aktarımını mümkün kılan olanak elde edilmiştir. Proje içinde yer alan 1. etap doğrudan kamulaştırma işlemlerini içermektedir. Kamulaştırma Kanunu'nun 8. maddesiyle maliklerle anlaşarak yapılan işlemlerde rezerv alan içinde belediye tarafından özel sektöre kat karşılığı yaptırılarak elde edilen konutlar-işyerleri verilebileceği gibi buradaki konutların satışı ile elde edilecek gelirlerin bedelinin 
verilmesi mümkün olacaktır. Bu proje kapsamında kullanılması amacıyla Çevre ve Şehircilik Bakanlığı'nca ilan edilmiş rezerv alan miktarı 30 milyon metrekare bir alanı kaplamaktadır. Üçüncü rezerv alan olarak belirlenen askeri alanın (Sille cephanelik) cazip, kente yakın, ilgili alanda prestij bir projenin yürütülüyor olması tarihi kent merkezinde hak kaybına uğramış maliklerin burada elde edilecek daireleri daha fazla istemesine neden olacaktır. $\mathrm{Bu}$ durum dönüşümün koruma ilkeleri doğrultusunda gerçekleşmesi noktasında güçlü finans desteği vermektedir.

İkinci Rezerv alan olarak belirlenen Ankara Yolu üzerindeki Aşağı Pınarbaşı Mahallesi'ndeki araziler ise plan amaçları doğrultusunda yapılaşmaları amacıyla satılması sağlanacaktır. Buradan elde edilecek gelirle, riskli ve rezerv alanda yapılacak kamulaştırma bedellerinin ve teknik alt yapı ve sosyal-kültürel-eğitim donatı alanlarının yapım maliyetleri karşılanacaktır. Birinci rezerv alan ilan edilen alan ise rezerv alan ilanı yaparak belediyeye diğer iki alanı devreden Çevre ve Şehircilik Bakanlığı- TOKI tarafından kullanılacaktır. Bu durumda riskli alanda ve rezerv alanda gerçekleşen yapılaşma vergi indirimi, hibe veya kredi olanakları sağlayan merkezi hükümete geri dönüş sağlanmış olacaktır.

Planlama sürecinde koruma planlarının gerçekleşmesinin önündeki en büyük engel olan finansal olanakların 2863 sayılı Kültür ve Tabiat Varlıklarını Koruma Kanun'un 17/c maddesi ile 6306 Afet Riski Altındaki Alanların Dönüştürülmesi Hakkında Kanun'un bir arada kullanılmasını içeren uygulama aracı geliştirilmiştir. Çevre ve Şehircilik Bakanlığı'nca kent merkezinde belirlenen rezerv arazilerin, dönüşümü gerçekleştirecek idare olan Konya Büyükşehir Belediyesi'ne devrinin sağlanmasıyla dönüşüm için güçlü finansal aracı elde edilmiştir. Bu durum, dönüşümü ve dönüşümün koruma odaklı olarak yürütülmesini sağlayan temel etken olmuştur.

\subsubsection{Kentsel dönüşüm projesi uygulama aşaması}

Uygulama aşamasında; tarihi kent merkezi dönüşüm sürecinde uzun vadeli uygulamaları yönetme, katılımcı süreç, kültürel mirasın yönetimi, ortaklıklar kamu- özel sektörün rolü çerçevesinde değerlendirilmiştir.

Türkiye'de bu tür alanlar kentin ticari merkezi olan değerli alanları da ifade ettiğinden dönüşümün gerçekleşebilmesi için klasik olarak planda güçlü bir ilave yapılaşma hakkı (bonus) sağlayarak, yeni yapılaşmanın finansının karşılanabileceği düşünülecektir. Ancak bölgenin tarihi kent merkezi dönüşüm stratejisi ve koruma alanı statüsüne sahip olması ilave inşaat hakkının verilmesine engel olmaktadır. Koruma amaçlı imar planı nedeniyle mevcut yapılaşma yoğunluğundan daha az değerlere düşürülmesi nedeniyle, yeniden yapılaşma ile ilgili farklı yöntem ve finans araçları ve dönüşüm yönetimini içeren süreç esaslı dönüşüm etaplarına ihtiyaç bulunmaktadır (Şekil 10).

Koruma odaklı dönüşüme esas planlama çalışmalarında belirlenen etapların kısa vade içinde (5 yıl) yapılması amaçlanan 1.etabı, yoğun kamulaştırma çalışmaları içerecektir. Kamulaştırma maliyetlerinin karşılanması için Çevre Şehircilik Bakanlığı'nca Konya Büyükşehir Belediyesi'ne devredilen rezerv alanlarda gerçekleştirilecek projelerden elde edilen gelirler kullanılacaktır. Bu rezerv alanlardan birinde Bizim Şehir Projesi'ne ait planlama, mimari proje ve kentsel tasarım çalışmaları Konya Teknik Üniversitesi tarafından yürütülmektedir. Bu kapsamda araç olarak kullanılan rezerv alan, bir kısmı doğrudan satışı veya hasılat paylaşımı sistemine bağlı olarak elde edilecek gelirlerle kısa vadede yapılacak kamulaştırmalar (1.etap) için kullanılacaktır. 
2.etabın dönüşüm esası, 2863 sayılı yasanın 17/c maddesinde belirlenen usuller çerçevesinde 1.etap çalışmaların tamamlanması, herhangi bir nedenle koruma amaçlı planın kararlarından geri adım atılmaması, yıkıp yapmaktan ziyade yenileme iyileştirme ve bina ve çevresinin güzel bir görünüme kavuşmasıdır. Türkiye'nin ve Konya'nın değişen ekonomik koşulları ile halkın dönüşüm algısına ve katılımına bağlı olarak orta ve uzun vadede (5-10-20 y1l) içinde birbirini takip etmek esasıyla belediye tarafindan izlenebilecek üç dönüşüm senaryosu söz konusu olacaktır;

Birinci senaryo; koruma amaçlı planda yapılaşma hakları kısıtlanmış olsa da 1.etabın zaman içerisinde getirdiği ticari canlılıkla 2.etap içindeki bina maliklerinin yerinde ve özel sektörle kat karşılığı anlaşmalar yaparak yeni yapılaşmaya gidebilmesinin mümkün olması halinde transfer edilecek bir hak söz konusu olmayacaktır. Dönüşüm stratejisinin bir başarısı olarak rezerv alanın ekonomik kullanımı ile kent içindeki farklı alanlarda yapılacak riskli alanların dönüşüm çalışmalarında kullanılması sağlanacaktır.

İkinci senaryo; 2.etap içinde yapı müteahhitleriyle bina malikleri arasında kat karşılı̆̆ anlaşmalar yapılarak yeni yapılaşmaya gidilmesi esastır. Ancak karşılıklı anlaşmalarının olmaması halinde koruma amaçlı planda yapılaşma hakları kısıtlanan taşınmazın kısıtlanan değeri SPK lisanslı gayrimenkul şirketi ve belediye bünyesinde kurulan değer tespit komisyonunca belirlenecektir. Rezerv alanda özel sektörle yapılan kat karşıllı̆ 1 anlaşmalarla belediye tarafindan elde edilen konut, işyerleri veya karşılığı bedelin hakları kısıtlanan maliklere veya kat karşılığı inşaat taahhüdü veren müteahhide verilmesi sağlanacaktır. Burada kısıtlanan hak değerlendirilirken 2. etapta koruma amaçlı plana göre yapılaşma hakkı kısıtlanarak yapılan binanın yapımı için gerekli maliyet, müteahhit ve mal sahibi payı hesaplanabilir. Müteahhit veya mal sahibin hak kaybı rezerv alandan karşılanır. Tüm bu işlemler malikler-müteahhit -belediye arasında yapılan anlaşmalarla sağlanmaktadır. 


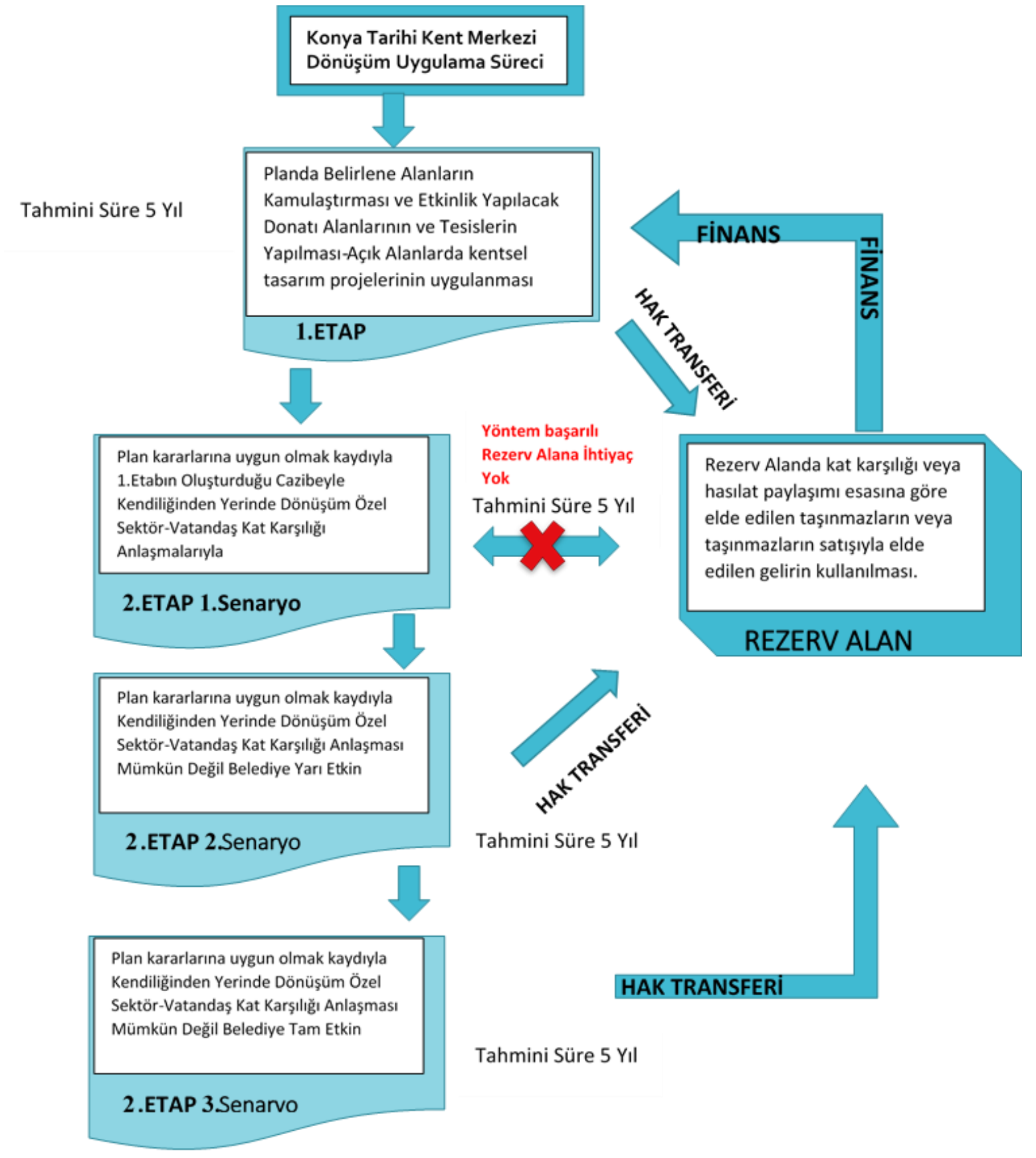

Şekil 10. Konya tarihi kent merkezi koruma odaklı dönüşüm ve uygulama süreci [Yazarlar tarafından oluşturulmuştur].

Üçüncü senaryo; 2 etap içinde dönüşümün özel sektör eliyle gerçekleşmemesi halinde 2 etap içinde belirlenen etaplar halinde yenileme veya dönüşüm maliyetleri rezerv alandaki arsa veya konut satışından elde edilen gelirlerin belediye tarafından kullanılması, belediyenin yasal dönüşüm araçları kullanan (dönüşüm alanı ilan etmek vb.) müteahhit rolüne girerek dönüşümü kâr amac1 gütmeden tamamlaması sağlanacaktır.

Belediye tarafindan rezerv alanda yapılacak arsa-konut satışına dair gelirlerin tarihi kent merkezi içinde harcanması sorumluluğu Konya Büyükşehir Belediyesi'nde, takip ve denetimi Çevre ve Şehircilik Bakanlığı'ndadır. Özellikle 2. etabın gerçekleştirilmesi sürecinde 2863 say1lı Kanun'un 17/c maddesinde belirtilen Sermaye Piyasası Kurulu'nca 
onaylı gayrimenkul değerleme şirketlerince değer tespitleri yapılacaktır. Burada tespit edilen değerin tamamı aktarım alanı (rezerv alan) olarak belirlenen alandan karşılanmak üzere konut-arsa-bedel unsurlarından hangisinin kamulaştırmaya veya oransal bir değer üzerinden trampaya (konut veya arsa olarak) konu olduğunu belirlenmesi gerekmektedir.

\subsection{Tartışma}

Özellikle korunan alanlarda yıllar içinde oluşmuş yapı yığınlarının kısa bir zaman dilimi içerisinde tamamen yıkılarak yeni bir yapılaşmaya gidilmesi beklenmemelidir. Bir bütün halinde yeni yapılaşma, korunması gerekli alana ait kent hafızasını ve zamanla oluşmuş dönemsel mimari dokunun yok edilmesini ve mimari kimliğe aykırı yeni yapılaşmaların yapılması riskini beraberinde taşımaktadır. Ayrıca bölgede yerinde ve kendiliğinden dönüşüm amaçlandığından mevcut binaların (2.etapdaki) mutlaka yıkılarak yapılmasından çok iyileştirilmesi, bakım ve onarımının sağlanarak güzel bir görünüm kazandırılması düşüncesi finans yaklaşımı ile koruma yaklaşımını birleştirmektedir.

Konya tarihi kent merkezi kentsel dönüşüm süreci kapsam belirleme, planlama, finansman ve uygulama aşamaları ile değerlendirildiğinde literatürde tanımlanan bilgilerin pratiğe aktarılmasına yönelik olumlu bir çalışmadır. Vizyon hazırlama süreci, toplumsal olarak fikir birliği oluşturmak için kullanılmıştır. Dönüşüm planı, farklı kurumlar arasında çeşitli görevleri paylaştırma ve kurumlar arası iş birliğini teşvik etmek için bir sistem önermiştir. Genel planlama hedeflerine uyumlu ve alana özgü kararlar içermektedir. Projenin finansman modelinin geliştirilmesi sürecinde özel sektörün ve kamu iş birliğinin sağlanmasına yönelik alternatif oluşturacak senaryolar geliştirilmiştir. Gerek 6306 sayılı Kanun ve gerekse 2863 sayılı Kanun'un sunduğu araçların çeşitliliği uygulama sürecini hızlandıracaktır. Aktör çeşitliliğinin sağlanması, sorunların ve taleplerin değerlendirilmesi süreci de başarılı bir şekilde işletilmiştir. Ancak sürece halk katılımının sağlanması konusunda yeni düzenlemeler gerektiğini de söylemek mümkündür.

Projenin başarısı ve sürdürülebilirliği için katılım önemlidir. Kamu katılımı, etkin bir şekilde yapılırsa, projenin başarılı olma sonucunu artırabilir. Ayrıca, katılım, kendisini, yanlış bilgilendirilmiş muhalefet ve protesto olarak tezahür ettirebilecek kamu çıkarını kanalize etmenin olumlu bir yolu olarak görülmelidir [9].

Herhangi bir kentsel dönüşüm projesinin başarısı her şeyden önce, arkasındaki politik liderliğe bağlıdır [9]. Konya tarihi kent merkezi kentsel dönüşüm projesi liderlik rolünün tanımlandığı ve sınırlarının çizildiği bir örnektir. Ancak proje sürecini olumsuz etkileyecek parçacıl değişikliklere imkân veren birtakım girişimlerin varlığı, bütüncül yaklaşımı sekteye uğratırken, kent çeperindeki alanlarda nüfus yoğunluğunun artmasıyla kentsel yayılma problemine de neden olabilecek gelişimler oluşturmaktadır. Bu durum kentsel dönüşüm projesinde yetki dağılımının süreçte değişiklikler içererek parçalanmasına yönelik müdahalelere engel olunması gerektiğini göstermiştir.

\section{Sonuç}

Konya Kenti tarihi kent merkezi dönüşüm sürecinin kapsam belirleme aşamasının Luanda ve Umbria örnekleriyle, planlama aşamasının Xintiandi, Cape Town ve Johannesburg örnekleriyle, finansman aşamasının Umbria ve Luanda örnekleriyle, uygulama aşamasının da Luanda ve Cape Town örnekleriyle benzeştiği belirlenmiştir. Kapsam 
belirleme aşamasında koruma odaklı strateji ile entegre ve bütünleşik bir yaklaşım benimsenmiş; planlama aşamasında uygulama etapları ve öncelikli alanlar belirlenmiş ve uygulamanın hızlanmasına yönelik onay sürecinde kamu desteği sağlanmış; finansman aşamasında yerel yönetim ile merkezi yönetimin rezerv arazilere ilişkin desteği, yönetmelik düzenlemeleri ve imar hakkı transferi gibi finansal araçlar değerlendirilmiş; uygulama aşamasında da süreç esaslı dönüşüm ve farklı dönüşüm senaryoları çerçevesinde aktörlerin etkinlik düzeyi belirlenmiş ve tüm paydaşlara rol verilmesine yönelik bir uygulama süreci tasarlanmıştır (Tablo 2.).

Tablo 2. Konya Kenti tarihi kent merkezinin dönüşümünün aşamaları ve benzer örnekler.

\begin{tabular}{|c|c|c|c|c|c|c|}
\hline $\begin{array}{c}\text { Uygulama } \\
\text { Ölçeği }\end{array}$ & Ülke & $\begin{array}{l}\text { Örnek } \\
\text { Alan }\end{array}$ & Kapsam & Planlama & Finansman & Uygulama \\
\hline $\begin{array}{l}\text { Kent } \\
\text { merkezi }\end{array}$ & Türkiye & $\begin{array}{l}\text { Konya } \\
\text { Tarihi } \\
\text { Kent } \\
\text { Merkezi }\end{array}$ & $\begin{array}{l}\text { • Korum odaklı } \\
\text { dönüşüm } \\
\text { stratejisi, } \\
\text { kültürel çevre } \\
\text { ve tarihi } \\
\text { koruma. } \\
\text { • Entegre ve } \\
\text { bütünleşik bir } \\
\text { yaklaşım. } \\
\text { • Frrsat ve } \\
\text { engellerin } \\
\text { belirlenmesi }\end{array}$ & $\begin{array}{l}\text { - Stratejiler } \\
\text { doğrultusunda bölge, } \\
\text { uygulama etapları ve } \\
\text { öncelikli alanların } \\
\text { belirlenmesi } \\
\text { • Karma kullanımın } \\
\text { değerlendirilmesi, yapı } \\
\text { yoğunluğunun } \\
\text { azaltılması } \\
\text { • Aktörlerin süreci } \\
\text { etkileme durumunun } \\
\text { tespiti, uygulamayı } \\
\text { hızlandırmak için onay } \\
\text { prosedürlerinde kamu } \\
\text { tarafindan destek } \\
\text { sunulması }\end{array}$ & $\begin{array}{l}\text { • Yerel } \\
\text { yönetimin } \\
\text { finansal araçları } \\
\text { ile teşvikler } \\
\text { • Yönetmelikler } \\
\text { • Çevre ve } \\
\text { Şehircilik } \\
\text { Bakanlığı'nca } \\
\text { kent merkezinde } \\
\text { belirlenen rezerv } \\
\text { arazilerin } \\
\text { belediyeye devri } \\
\text { • İmar hakkı } \\
\text { transferi }\end{array}$ & $\begin{array}{l}\text { • Süreç esaslı } \\
\text { dönüşüm } \\
\text { • Üç farklı } \\
\text { dönüşüm } \\
\text { senaryosu } \\
\text { • Aktörlerin } \\
\text { etkinlik düzeyi } \\
\text { belirlenmiştir } \\
\text { • Tüm } \\
\text { paydaşlara } \\
\text { roller } \\
\text { verilmiştir }\end{array}$ \\
\hline \multicolumn{3}{|c|}{$\begin{array}{l}\text { Kentsel dönüşüm aşamaları } \\
\text { bakımından benzer nitelikteki } \\
\text { örnekler }\end{array}$} & $\begin{array}{l}\text { Luanda } \\
\text { Metropoliten } \\
\text { Alanı } \\
\text { Umbria } \\
\text { Bölgesi Tarihi } \\
\text { Kent Merkezi }\end{array}$ & $\begin{array}{l}\text { Luwan-Taipingqiao } \\
\text { Mahallesi } \\
\text { Xintiandi Bölgesi } \\
\text { Tarihi Kent Merkezi } \\
\text { Cape Town } \\
\text { Khayelitsha Merkezi İş } \\
\text { Alanı } \\
\end{array}$ & $\begin{array}{l}\text { Umbria Bölgesi } \\
\text { Tarihi Kent } \\
\text { Merkezi } \\
\text { Luanda } \\
\text { Metropoliten } \\
\text { Alanı }\end{array}$ & \begin{tabular}{|l} 
Cape Town \\
Khayelitsha \\
Merkezi İş \\
Alanı \\
Luanda \\
Metropoliten \\
Alanı \\
\end{tabular} \\
\hline
\end{tabular}

Konya tarihi kent merkezi vizyon hazırlama süreci fikir birliği oluşturmak amaciyla gerçekleştirmiştir ve tıpkı Luanda örneğinde olduğu gibi bütüncül özellik taşımaktadır. Metropoliten alanda planlanmış her iki projede de dönüşüm kent bütününden bağımsız olarak düşünülmemiş, aksine etkileri kent genelinde değerlendirilmiştir. Kurumlar ve aktörler arasında işbirliğini ve rol paylaşımını gündeme getirmiştir. Kültürel ve tarihi çevreyi korumaya yönelik stratejiler geliştirilen Umbria örneği gibi koruma odaklı dönüşüm stratejisi belirlenmiş ve alanın sahip olduğu tüm değerlerin korunması öncelik taşımıştır.

Planlama çalışmaları, yürürlükte olan tüm kademelerdeki planlar ve raporları dikkate alınarak gerçekleştirilmiştir. Johannesburg kent merkezinin dönüşümü için belirlenen yol haritası gibi, Konya örneğinde de alternatifli senaryolar belirlenerek detaylı bir yol haritası oluşturulmuştur. Konya ve Johannesburg dönüşüm projelerinde, mevcutta karşılaşılan suçu önlemeye/ azaltmaya yönelik hedef ve kararlar geliştirilerek güvenli mekânların oluşturulmasını amaçlamıştır.

Konya tarihi kent merkezinin dönüşümünün sağlanması için gerekli finansal araçlar imar hakkı transferi, yasa ve yönetmelikler çerçevesinde oluşturulmuştur. Bu çerçevede Konya 
örneği, imar hakkı transferi yöntemini benimseyen Luanda ve Umbria örnekleri ile benzerlik taşımaktadır. Finansal planlama mekanizmalarının sağlanmasında kamu sektörü sorumlu aktör olmuştur. İmar hakkının transferi ile bahsedilen örnek projelerde maliyet avantajı elde edilmiştir.

Cape Town örneğinde olduğu gibi uygulama aşamasında tüm paydaşlara roller verilmiş ve Luanda örneği gibi aktörlerin entegre şekilde çalışması hedeflenmiştir. Ancak Luanda metropoliten alanının dönüşüm stratejisinde ortaya konan modeller hedeflediği başarıyı elde edememiştir. Aktörler arasında etkili bir koordinasyonunun sağlanamamış olması hedeflerin gerisinde kalınmasına neden olmuştur. Ekonomik yönleri dikkate alan bir yeniden yapılanma örneği Luanda'da sağlanan büyüme etkisi, Konya'da ticaretin canlılığının artırılması ve turizmin desteklenmesi şeklinde görülmektedir.

Kentsel dönüşüm sürecinde farklı örneklerin incelenmesi, kentsel dönüşüm sürecine ilişkin anahtar bir çerçeve oluşturulmasına yardımcı olmuştur. Ancak, bu çalışma ile ortaya konulan süreç ve örnek araçların evrensel olarak tüm kentler için geçerli olacağını söylemek mümkün değildir. Bu noktada, iyi uygulama örneklerinden faydalanarak her kent için kendi yönetim, mülkiyet ve yasal çerçevelerine uygun, özgün yaklaşımların uyarlanabileceğini vurgulamak gereklidir.

Koruma olgusu ile birlikte değerlendirilmesi gereken kentsel dönüşüm çalışmaları yerel yönetimlerin kâr amacı gözetmeksizin yürütmesi gereken bir dizi stratejiyi içermelidir. Ayrıca kent bütünü içinde tarihi kent merkezinin dönüşümü aracılığıyla ticari merkezin bütünüyle cazibesini yitiren bir alan olması engellenmelidir. Tarihi kent merkezi bir taraftan turistlerin ilgi duyduğu bir alan olarak faaliyetine devam ederken diğer taraftan da gündelik yaşam içinde halkın ilgi duyduğu sosyal- kültürel aktivitelerin ve ticari faaliyetin devam edeceği alan olması sebebiyle dikkatli bir planlama-yönetişim faaliyeti yürütülmelidir. Bu bağlamda, kent bütününden kopuk bir dönüşüm çalışmasının olumlu etkilerinin sınırlı olacağı unutmamalı ve planlama süreci tüm bu derslerden çıkarımlar ile tanımlanmalıdır.

\section{Kaynaklar}

[1] Couch, C., Urban renewal: Theory and practice, Macmillan International Higher Education, London, (1990).

[2] Chaline, C. and H. Coccossis, Guidelines for urban regeneration in the Mediterranean region, UNEP, Priority Actions Programma, Regional Activity Centre, Split, (2004).

[3] İlkme, M., Kentsel dönüşüm ve Bursa raporu, TMMOB Şehir Plancıları Odası Bursa Şubesi, (2008).

[4] Akkar, Z.M., Kentsel dönüşüm üzerine Batı'daki kavramlar, tanımlar, süreçler ve Türkiye, Planlama, 2, 29-38, (2006).

[5] Amado, M.P. vd., Regeneration of informal areas: An integrated approach, Cities, 58, 59-69, (2016).

[6] Donaldson, R. ve D. Du Plessis, The urban renewal programme as an area-based approach to renew townships: The experience from Khayelitsha's Central Business District, Cape Town, Habitat International, 39, 295-301, (2013).

[7] Lichfield, D., Organisation and management, in P. Roberts and H. Sykes, Urban regeneration, SAGE, London. p. 228-255, London, (2000). 
[8] Roberts, P., The evolution, definition and purpose of urban regeneration, in P. Roberts and H. Sykes, Urban regeneration, SAGE, 9-36, London, (2000).

[9] Amirtahmasebi, R., vd., Regenerating Urban Land Regenerating Urban Land, Dünya Bankası, Washington, 3-86, (2016).

[10] https://urban-regeneration.worldbank.org/, (21.12.2018).

[11] Amirtahmasebi, R., vd., Shanghai: Regenerating a Historic Neighborhood through Commercial Development, in R. Amirtahmasebi, et al. Regenerating Urban Land Regenerating Urban Land, Dünya Bankas1, Washington, 221-252, (2016).

[12] Adair, A., et al., The financing of urban regeneration. Land Use Policy, 17, 2, 147-156, (2000).

[13] Amirtahmasebi, R., vd., Johannesburg: Aligning Diverse Prophecies for Revitalizing a Declining Inner City, in R. Amirtahmasebi, et al. Regenerating Urban Land Regenerating Urban Land, Dünya Bankas1, Washington, 385-420, (2016).

[14] Falco, E., Transferable development rights in regeneration schemes for historic city centres. Legislation in the Umbria Region, Italian Journal of Planning Practice, 2, 2, 4-14, (2014).

[15] Cameron, S., Gentrification, housing redifferentiation and urban regeneration:'going for growth'in Newcastle upon Tyne, Urban Studies, 40, 12, 2367-2382 (2003).

[16] Erdem, R. vd., Konya tarihi kent merkezi kentsel koruma ve dönüşüm strateji raporu, Konya Büyükşehir Belediyesi, (2016).

[17] Konya Büyükşehir Belediyesi, (2018).

[18] Yenice, M.S., Konya kentinin planlama tarihi ve mekansal gelişimi, Erciyes Üniversitesi Fen Bilimleri Enstitüsü Dergisi, 28, 4, 343-350, (2012).

[19] Mengilli-Işı1dak, F., Koruma Alanlarında imar hakları transferi ve ABD modeli, Kültür ve Turizm Bakanlığı Uzmanlık Tezi, (2012).

[20] Şehircilik şurası komisyon raporları, Çevre ve Şehircilik Bakanlığı, (2017).

[21] Konya diş kale surları raporu, Konya Büyükşehir Belediyesi, (2015).

[22] Ekizer, D.E. vd., Asayiş ve trafik olaylarina ait bilgilerin mekânsal analizler ile değerlendirmesi- Konya örneği, TMMOB Coğrafi Bilgi Sistemleri Kongresi, Antalya, (2011).

[23] Gül, M., Antalya kent merkezi kültür ve turizm gelişim bölgesinde yer alan sit alanları ve bu alanlarda Antalya Büyükşehir Belediyesince başlatılan çalışmalara ilişkin genel bir değerlendirme, Planlama, 4, 38, 121-145, (2006). 